University of South Carolina

Scholar Commons

Faculty Publications

Law School

$12-2018$

\title{
Plea Agreements as Constitutional Contracts
}

Colin Miller

University of South Carolina - Columbia, mille933@law.sc.edu

Follow this and additional works at: https://scholarcommons.sc.edu/law_facpub

Part of the Law Commons

\section{Recommended Citation}

Colin Miller, Plea Agreements as Constitutional Contracts, 97 N.C. L. Rev. 31 (2018).

This Article is brought to you by the Law School at Scholar Commons. It has been accepted for inclusion in Faculty Publications by an authorized administrator of Scholar Commons. For more information, please contact digres@mailbox.sc.edu. 


\title{
PLEA AGREEMENTS AS CONSTITUTIONAL CONTRACTS*
}

\author{
COLIN MILLER ${ }^{* *}$
}

In his dissenting opinion in Ricketts $\mathrm{v}$. Adamson, Justice Brennan proposed the idea of plea agreements as constitutional contracts and lamented the fact that the Supreme Court had yet to set up rules of construction for resolving plea-deal disputes. Since Adamson, courts have given lip service to Justice Brennan's dissent and applied his reasoning in piecemeal fashion. No court or scholar, however, has attempted to define the extent to which a plea agreement is a constitutional contract or develop rules of construction to apply in plea-deal disputes. This gap is concerning given that ninety-five percent of criminal cases are resolved by plea agreements.

This Article is the first attempt to defend the concept of plea agreements as constitutional contracts and establish a core rule of construction to guide judges in interpreting plea bargains. It advances the thesis that due process requires that courts treat pleading defendants at least as well as parties to other contracts, meaning all of the protections associated with contract law should be incorporated into plea-bargaining law through the Due Process Clause.

This Article then argues that incorporation of one of these protections-the implied covenant of good faith and fair dealing-would lead to legal reform in three plea-bargaining scenarios where pleading defendants are treated worse than parties to other contracts: (1) substantial assistance motions, (2) Brady disclosures, and (3) prosecutorial presentation of sentencing recommendations.

* (C) 2018 Colin Miller.

** Professor and Associate Dean for Faculty Development, University of South Carolina School of Law; Editor, EvidenceProf Blog; Co-Host, Undisclosed Podcast. I would like to thank Zoe Miller, Marie Boyd, and Ben Means for the helpful comments on this Article. 
INTRODUCTION .33

I. A BRIEF HISTORY OF PLEA BARGAINING .................................34

II. Plea AgreEMENTS AS CONSTITUTIONAL CONTRACTS...........35

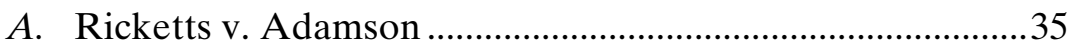

B. Subsequent Case Law on Plea Agreements as

Constitutional Contracts ........................................................39

C. Plea-Bargaining Criminal Defendants Should Be

Treated at Least as Well as Parties to Other

Government Contracts....

III. PleA AGREEMENTS AS CONSTITUTIONAL CONTRACTS AND THE IMPLIED COVENANT OF GOOD FAITH AND FAIR DEALING

A. Origin of the Implied Covenant of Good Faith and Fair Dealing.....

B. The Modern Implied Covenant of Good Faith and Fair Dealing.

C. The Implied Covenant and Government Contracts..............52

D. The Implied Covenant and Plea Agreements ........................53

E. Applying the Implied Covenant to Three Key Plea-

Bargaining Situations ...

1. Discretionary Government Decisions.............................55

a. Substantial Assistance Motions

i. United States Sentencing Guidelines and Sentencing Ranges

ii. Substantial Assistance Motions for Downward Departures ...

iii. Prosecutorial Discretion over Substantial Assistance Motions .58

iv. Failure to File and Prosecutorial Breach...........59

v. Applying the Implied Covenant to

Substantial Assistance Motions 64

2. The Duty to Disclose Material Evidence.

a. Brady v. Maryland and Plea Agreements....

b. The Implied Covenant and the Superior Knowledge Doctrine . .71

c. Applying the Implied Covenant to Brady Evidence.... .73

3. The Affirmative Duty to Cooperate ...............................78

a. Benchimol and the Duty Not to Undermine ..............79

b. The Duty to Cooperate and Not to Hinder.................8 84 


\section{c. Applying the Implied Covenant to Presentation} of Sentencing Recommendations ...............................8 86

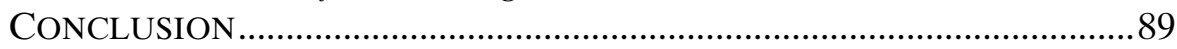

\section{INTRODUCTION}

In his 1987 dissenting opinion in Ricketts v. Adamson, ${ }^{1}$ Justice Brennan proposed the idea of plea agreements as constitutional contracts:

This Court has yet to address in any comprehensive way the rules of construction appropriate for disputes involving plea agreements. Nevertheless, it seems clear that the law of commercial contract may in some cases prove useful as an analogy or point of departure in construing a plea agreement, or in framing the terms of the debate. ${ }^{2}$

In the thirty years since Adamson, courts have given lip service to Justice Brennan's dissent and applied his reasoning in piecemeal fashion in cases involving disputes over plea bargains. No court or scholar, however, has ever attempted to develop clear rules of construction to apply in plea-bargaining disputes. This gap in the law is surprising and concerning given that approximately ninety-five percent of criminal cases in this country are now resolved by plea agreements. $^{3}$

This Article is the first attempt to establish a core rule of construction to guide judges in interpreting plea bargains. It advances the thesis that due process requires that courts treat pleading defendants at least as well as parties to other contracts, meaning that all of the protections associated with contract law should be incorporated into plea-bargaining law through the Due Process Clause. This Article then argues that incorporation of one of these contract law protections - the implied covenant of good faith and fair dealing-would lead to legal reform in three key plea-bargaining scenarios where pleading defendants are treated worse than parties to other contracts.

This Article proceeds in three parts. Part I of this Article provides a brief history of plea bargaining. Part II analyzes Justice Brennan's dissent and advances the theory of plea agreements as

1. 483 U.S. 1 (1987).

2. Id. at 16 (Brennan, J., dissenting).

3. State v. Finney, 834 N.W.2d 46, 49 (Iowa 2013). 
constitutional contracts. Finally, Part III argues that this theory would result in substantial reform to three key plea-bargaining scenarios: (1) substantial assistance motions, (2) Brady disclosures, and (3) prosecutorial presentation of sentencing recommendations.

\section{A Brief History of PleA BARgAining}

In the United States, "plea bargaining did not occur with any frequency until well into the nineteenth century." 4 Toward the end of the nineteenth century and through the beginning of the twentieth century, plea bargaining became "a dominant method of resolving criminal cases" at the same time that there was a substantive expansion of criminal law. ${ }^{5}$ In the decades following the 1920 s, plea bargaining became an even more central part of the criminal justice system, despite disapproval by scholars and the press. ${ }^{6}$

The major reason for this disapproval was the fact that plea bargaining occurred in an informal and clandestine manner. ${ }^{7}$ There was "a ritual of denial that any promises ha[d] been made, a ritual in which judges, prosecutors, and defense counsel ... participated." ${ }^{8}$ As a result, there was "a lack of effective judicial review of the propriety of the agreements, thus increasing the risk of real or apparent unfairness."

The first attempt to regulate plea bargaining came in 1946, when Congress promulgated Federal Rule of Criminal Procedure $11 .{ }^{10}$ At the time, Rule 11 simply stated that a judge should not accept a guilty plea "without first determining that the plea is made voluntarily with understanding of the nature of the charge."11 In 1966, the Supreme Court amended Rule 11 to prohibit a judge from accepting a guilty plea "without first addressing the defendant personally and determining the plea is made voluntarily with understanding of the nature of the charge and the consequences of the plea." 12

Despite the Supreme Court's amendment to Rule 11, the Court itself noted that it was not until its 1971 opinion in Santobello v. New

4. Albert W. Alschuler, Plea Bargaining and Its History, 79 COLUM. L. REV. 1, 5

5. Id. at 6. This expansion was largely the result of Prohibition. Id.

6. Id.

7. FED. R. CRIM. P. 11 advisory committee's notes to 1974 amendment.

8. Id.

9. Id.

10. FED. R. CRIM. P. 11 (1946) (amended 1966); see also State v. Finney, 834 N.W.2d 46, 51 (Iowa 2013).

11. FED. R. CRIM. P. 11 (1946) (amended 1966).

12. FED. R. CRIM. P. 11 (1966) (amended 1974). 
York "13 "that lingering doubts about the legitimacy of the practice were finally dispelled." 14 In Santobello, the Court recognized that there would need to be a significant expansion in the number of judges and court facilities if every criminal charge were taken to trial. ${ }^{15}$ Therefore, the Court concluded that "[ $\left.\mathrm{t}\right]$ he disposition of criminal charges by agreement between the prosecutor and the accused, sometimes loosely called 'plea bargaining,' is an essential component of the administration of justice." 16 As such, "[p]roperly administered, it is to be encouraged." ${ }^{17}$

Since Santobello, plea bargaining has become the predominant method of resolving criminal charges in this country. Currently, about ninety-five percent of criminal cases that are not dismissed are resolved with plea bargains. ${ }^{18}$ This shift to plea bargaining has led scholars to bemoan the death of the jury trial. ${ }^{19}$

\section{Plea Agreements as Constitutional Contracts}

The 1987 Supreme Court case Ricketts v. Adamson highlighted the fact that there have never been rules of construction created for plea agreements, but it did not define the extent to which commercial contract law informs plea-bargaining law. Nonetheless, subsequent precedent, including Supreme Court precedent, makes clear that defendants entering into plea agreements should be treated at least as well as parties entering into commercial contracts.

In Adamson, the Supreme Court was given the opportunity to determine the extent to which the Constitution informs the question of whether the prosecution breached a plea agreement. A majority of the Court, however, failed to answer the question.

\section{A. Ricketts v. Adamson}

In Ricketts v. Adamson, a reporter for the Arizona Republic was killed when a dynamite bomb exploded under his car, and the State charged John Adamson with first-degree murder in connection with

13. 404 U.S. 257 (1971).

14. Blackledge v. Allison, 431 U.S. 63, 76 (1977) (discussing the holding of Santobello, which established the necessity of the practice of plea bargaining).

15. Santobello, 404 U.S. at 260.

16. Id.

17. $I d$.

18. See State v. Finney, 834 N.W.2d 46, 49 (Iowa 2013).

19. See, e.g., Norman W. Spaulding, Due Process Without Judicial Process?: Antiadversarialism in American Legal Culture, 85 FORDHAM L. REV. 2249, 2249 (2017). 
the crime. ${ }^{20}$ Adamson later entered into a plea agreement, pursuant to which he pleaded guilty to second-degree murder in exchange for his testimony against Max Dunlap and James Robison, who were also allegedly involved in the murder. ${ }^{21}$ Specifically, the plea deal stated in relevant part that "[s]hould the defendant refuse to testify or should he at any time testify untruthfully ... then this entire agreement is null and void and the original charge will be automatically reinstated." 22

Adamson thereafter testified against the two other men, who were convicted of first-degree murder. ${ }^{23}$ Pursuant to the plea agreement, the court then sentenced Adamson to 48 to 49 years' imprisonment, "with a total incarceration time of 20 years and 2 months." 24 On appeal, however, the Supreme Court of Arizona reversed the convictions of Dunlap and Robison based upon Confrontation Clause violations. ${ }^{25}$

Before retrial, the State informed Adamson that it intended to call him as a witness against the two men pursuant to his plea agreement. ${ }^{26}$ Defense counsel responded by sending a letter to the prosecutor indicating that Adamson believed his obligations under the plea agreement ended when he was sentenced. ${ }^{27}$ The State countered with its own letter stating that it believed Adamson to be in breach of his plea agreement. ${ }^{28}$ When the State thereafter called Adamson to testify at a pretrial proceeding in connection with the retrial of Dunlap and Robison, defense counsel told the judge about the prosecutor's letter. ${ }^{29}$ As a result, the judge did not compel Adamson to answer the prosecutor's questions at the proceeding. ${ }^{30}$

The State followed up by filing a new first-degree murder charge against Adamson, who moved to quash the charge on double jeopardy grounds. ${ }^{31}$ The Supreme Court of Arizona eventually found that (1) Adamson breached the plea agreement, which contemplated his testimony at "retrial after reversal"; and (2) Adamson waived his

\footnotetext{
20. Ricketts v. Adamson, 483 U.S. 1, 3 (1987).

21. Id.

22. Id. at 4.

23. Id.

24. Id.

25. State v. Dunlap, 608 P.2d 41, 44 (Ariz. 1980); see also Adamson, 483 U.S. at 4.

26. Adamson, 483 U.S. at 4.

27. Id. at $4-5$.

28. Id.

29. Id. at 5.

30. Id.

31. Id.
} 
double jeopardy objection under the terms of the plea agreement. ${ }^{32}$ That said, the court concluded that the prosecution should have reinstated the initial first-degree murder charge rather than bringing a new first-degree murder charge; therefore, it remanded the case after it vacated Adamson's second-degree murder conviction, reinstated the original first-degree murder charge, and dismissed the new firstdegree murder charge. ${ }^{33}$ At this point, Adamson offered to testify against Dunlap and Robison, but the prosecutor declined the offer. ${ }^{34}$ Adamson was later convicted of first-degree murder and given the death penalty. ${ }^{35}$

His appeal eventually reached the United States Supreme Court, which initially noted that "[u]nder the terms of the plea agreement, both parties bargained for and received substantial benefits." 36 The Court then found that the agreement made clear that Adamson "would have no double jeopardy defense" if he failed to hold up his end of the bargain. ${ }^{37}$ Because the United States Supreme Court agreed with its Arizona counterpart that Adamson breached the plea agreement, it found that he was not entitled to relief. ${ }^{38}$

In a dissenting opinion joined by Justices Marshall, Blackmun, and Stevens, Justice Brennan began by noting that the entire case hinged on whether Adamson breached the plea agreement. ${ }^{39} \mathrm{He}$ then used the following language:

This Court has yet to address in any comprehensive way the rules of construction appropriate for disputes involving plea agreements. Nevertheless, it seems clear that the law of commercial contract may in some cases prove useful as an analogy or point of departure in construing a plea agreement, or in framing the terms of the debate. It is also clear, however, that commercial contract law can do no more than this, because plea agreements are constitutional contracts. The values that underlie commercial contract law, and that govern the relations between economic actors, are not coextensive with those that underlie the Due Process Clause, and that govern relations between criminal defendants and the State. Unlike some

32. Id. at 5-6.

33. Id. at 7.

34. $I d$.

35. Id.

36. Id. at 9 .

37. Id. at 10

38. Id. at $11-12$.

39. Id. at 12 (Brennan, J., dissenting). 
commercial contracts, plea agreements must be construed in light of the rights and obligations created by the Constitution. ${ }^{40}$

Justice Brennan next observed that both the Arizona and United States Supreme Courts merely assumed that Adamson breached the plea deal without analyzing the facts under commercial contract law. ${ }^{41}$ He then argued that Adamson's letter could not be a regular breach because the plea deal did not require Adamson to agree with the State's interpretation of the plea agreement or refrain from sending such a letter. ${ }^{42}$ Further, Justice Brennan found that the letter was not an anticipatory breach of the plea deal because it merely advanced an alternative reasonable interpretation of the agreement and did not state a refusal to perform. ${ }^{43}$

Justice Brennan determined that the majority's opinion finding Adamson in breach was especially problematic because, "far from being a commercial actor, Adamson is an individual whose 'contractual' relation with the State is governed by the Constitution." ${ }^{44}$ Therefore, "[t]he determination of Adamson's rights and responsibilities under the plea agreement is controlled by the principles of fundamental fairness imposed by the Due Process Clause." 45 As a result, granting "one party-here, the State-the unilateral and exclusive right to define the meaning of a plea agreement is patently unfair." 46

Finally, Justice Brennan concluded that even if Adamson breached the plea agreement, the State had the duty, like a party to a commercial contract, to "take all reasonable steps to minimize the consequent damage." 47 According to Justice Brennan, while Adamson's actions might have delayed the retrials of Dunlap and Robison and cost the State some litigation expenses, Adamson was now prepared to fulfill his end of the bargain. ${ }^{48}$ Therefore, the State could have been made whole by accepting Adamson's testimony and exacting some minor penalty on Adamson, but a capital murder prosecution was too steep of a price. ${ }^{49}$ Justice Brennan found that (1)

40. Id. at 16 (citation omitted) (citing Blackledge v. Allison, 431 U.S. 63, 75 n.6

41. Id. at $16-17$.

42. $I d$. at 17

43. Id. at 18 .

44. Id. at 20 .

45. $I d$. at $20-21$.

46. Id. at 21 .

47. Id. at 22 .

48. Id.

49. Id. 
"[a] comparable result in commercial law, if one could be imagined, would not be enforced"; 50 and (2) "[t]he fundamental unfairness in the State's course of conduct here is even less acceptable under the Constitution." 51

Justice Brennan's dissenting opinion laid the groundwork for the concept of plea agreements as constitutional contracts. And yet, neither the Supreme Court nor lower courts have fleshed out the groundwork in the ensuing decades.

\section{B. Subsequent Case Law on Plea Agreements as Constitutional Contracts}

Given that Justice Brennan's conclusion that "plea agreements are constitutional contracts" came in a dissenting opinion, ${ }^{52}$ it is unsurprising that most courts have not explicitly cited it in their opinions. Two federal circuit courts have cited this language from Justice Brennan's dissent: the Third Circuit, in a dissenting opinion, ${ }^{53}$ and the First Circuit, in noting that the defendant had not claimed prosecutorial breach. ${ }^{54}$ Three federal district courts have quoted the language as well, all in unpublished opinions. ${ }^{55}$ Finally, a handful of state courts have cited Justice Brennan's dissent to find in favor of defendants. ${ }^{56}$

While most courts have not explicitly cited Justice Brennan's conclusion, the Supreme Court and all federal circuit courts, ${ }^{57}$ along

\footnotetext{
50. Id. at 23 .

51. Id.

52. Id. at 16 .

53. McKeever v. Warden SCI-Graterford, 486 F.3d 81, 97 (3d Cir. 2007) (Roth, J., dissenting).

54. United States v. Garcia-Rosa, 876 F.2d 209, 235 (1st Cir. 1989), vacated on other grounds sub nom. Rivera-Feliciano v. United States, 498 U.S. 954 (1990).

55. See Hughes v. Beard, No. 14-cv-01302-EMC, 2016 WL 126931, at *9 (N.D. Cal. Jan. 12, 2016); Holston v. Cate, No. 2:11-CV-00917-JKS, 2012 WL 6561729, at*6 (E.D. Cal. Dec. 14, 2012); United States v. Bell, Criminal Action No. H-07-271, 2008 WL 59188, at $* 1$ (S.D. Tex. Jan. 3, 2008).

56. See, e.g., Smith v. Commonwealth, 400 S.W.3d 742, 744 (Ky. 2013); State v. Louis, 645 So. 2d 1144, 1148 (La. 1994).

57. See Cuero v. Cate, 827 F.3d 879, 885 (9th Cir. 2016), rev'd, 138 S. Ct. 4 (2017); United States v. Villa-Vazquez, 536 F.3d 1189, 1199 (10th Cir. 2008); McKeever, 486 F.3d at 97 (Roth, J., dissenting); United States v. Debreczeny, 69 F. App'x 702, 706 (6th Cir. 2003); San Pedro v. United States, 79 F.3d 1065, 1075 (11th Cir. 1996); Margalli-Olvera v. INS, 43 F.3d 345, 351 (8th Cir. 1994); United States v. Martin, 25 F.3d 211, 216-17 (4th Cir. 1994); United States v. Pollard, 959 F.2d 1011, 1022 (D.C. Cir. 1992); United States v. Pelletier, 898 F.2d 297, 301-02 (2d Cir. 1990); United States v. Ataya, 864 F.2d 1324, 1329 (7th Cir. 1988); United States v. Papaleo, 853 F.2d 16, 18-19 (1st Cir. 1988); In re Geisser, 627 F.2d 745, 749 (5th Cir. 1980).
} 
with state supreme courts across the country ${ }^{58}$ have found that plea agreements are governed or strongly influenced by contract law, with defendants also afforded the additional protection of the Due Process Clause.

In its 2009 opinion in Puckett v. United States, ${ }^{59}$ the Supreme Court held that, "[a]lthough the analogy may not hold in all respects, plea bargains are essentially contracts." ${ }^{60}$ According to the Court, under commercial law, "[w]hen the consideration for a contract fails - that is, when one of the exchanged promises is not kept-we do not say that the voluntary bilateral consent to the contract never existed, so that it is automatically and utterly void; we say that the contract was broken." ${ }^{61}$ The Court applied this same analysis to plea agreements by analogy to commercial contract law, concluding that "it is hornbook law that misrepresentation requires an intent at the time of contracting not to perform." 62

The Supreme Court is not alone. Courts across the country frequently apply commercial contract law principles to plea bargaining. For instance, "[c]ourts have generally considered contract defenses like unclean hands and lack of meeting of the minds in evaluating whether a plea agreement should be voided."63 Courts have also applied the commercial contract law doctrines of mutual mistake of fact ${ }^{64}$ and frustration of purpose ${ }^{65}$ to void plea agreements and discharge the parties' obligations under such agreements.

Moreover, because it is the Due Process Clause that mandates the prosecution's performance ${ }^{66}$ many courts have placed a greater degree of responsibility on the government than they place upon criminal defendants and/or parties to private contracts. For instance, in United States v. Harvey, ${ }^{67}$ Michael Lee Harvey was charged with nine offenses related to drug smuggling and distribution operations. ${ }^{68}$ Harvey subsequently pleaded guilty to one charge in exchange for the prosecution dropping the remaining charges and agreeing to the

58. See, e.g., Ex parte Johnson, 669 So. 2d 205, 207 (Ala. 1995); In re Lord, 94 P.3d 952, 955 (Wash. 2004).

59. 556 U.S. 129 (2009).

60. Id. at 137.

61. Id.

62. Id. at $138 \mathrm{n} .1$.

63. Boswell v. Crews, No. 3:11cv352/RV/EMT, 2013 WL 1562940, at *20 (N.D. Fla. Feb. 25, 2013).

64. See, e.g., United States v. Bradley, 381 F.3d 641, 648 (7th Cir. 2004).

65. See, e.g., United States v. Bunner, 134 F.3d 1000, 1004-05 (10th Cir. 1998).

66. Ex parte Johnson, 669 So. 2d 205, 207 (Ala. 1995).

67. 791 F.2d 294 (4th Cir. 1986).

68. Id. at 295 . 
following clause: "The Eastern District of Virginia further agrees not to prosecute MICHAEL LEE HARVEY for any other possible violations of criminal law arising from the offenses set out in the indictment or the investigation giving rise to those charges."

Later, Harvey was indicted in connection with the same crimes in the District of South Carolina, and he moved in the Eastern District of Virginia for enforcement of the plea agreement and enjoinment of the South Carolina indictment. ${ }^{70}$ The Fourth Circuit agreed with Harvey, finding that the language was ambiguous as to whether the subject clause applied only in the Eastern District of Virginia or everywhere. $^{71}$

In reaching this conclusion, the Fourth Circuit held that "both constitutional and supervisory concerns require holding the Government to a greater degree of responsibility than the defendant (or possibly than would be either of the parties to commercial contracts) for imprecisions or ambiguities in plea agreements."72 This language about possibly holding the prosecution to a higher standard than parties to a commercial contract has proven to be pretty popular. It has since been cited by four other federal circuit courts, ${ }^{73}$ four state supreme courts,${ }^{74}$ and several federal district courts. ${ }^{75}$

In addition to numerous courts applying Harvey, several courts have also found that defendants may be entitled to relief, even when prosecutors do not violate specific terms of plea agreements, due to "general principles of due process and prosecutorial responsibility." Additionally, courts have concluded that due process sometimes requires courts to deviate from normal contract law to provide further protection to criminal defendants entering into plea agreements. ${ }^{77}$

Finally, courts have refused to apply some contract law principles to plea bargaining to protect the constitutional rights of defendants,

69. Id. at 295-96, $296 \mathrm{n} .1$

70. Id. at 297.

71. Id. at 303 .

72. Id. at 300 .

73. See United States v. Copeland, 381 F.3d 1101, 1106 (11th Cir. 2004); United States v. Clark, 218 F.3d 1092, 1095 (9th Cir. 2000); United States v. Johnson, 979 F.2d 396, 399 (6th Cir. 1992); United States v. Giorgi, 840 F.2d 1022, 1026-27 (1st Cir. 1988).

74. See People v. McClellan, 862 P.2d 739, 750-51 (Cal. 1993) (en banc); Cole v. State, 922 A.2d 364, 377 (Del. 2007); State v. Langley, 369 P.3d 1005, 1010 (Mont. 2016); State v. Bisson, 130 P.3d 820, 828 (Wash. 2006) (en banc).

75. See, e.g., United States v. Oruche, 257 F. Supp. 2d 230, 239 (D.D.C. 2003).

76. See, e.g., State v. Tyson, 189 N.C. App. 408, 416, 658 S.E.2d 285, 291 (2008).

77. See, e.g., McKeever v. Warden SCI-Graterford, 486 F.3d 81, 86 (3d Cir. 2007); United States v. Olesen, 920 F.2d 538, 542 (8th Cir. 1990); Loveless v. State, 896 N.E.2d 918, 921 n.3 (Ind. Ct. App. 2008). 
which seems consistent with the Puckett Court's conclusion that the analogy between contract law and plea-bargain law may not hold in all respects. ${ }^{78}$ For example, in United States v. Barron, ${ }^{79}$ William Scott Barron, Jr. entered into a plea agreement, pursuant to which he pleaded guilty to several crimes, including possession of a firearm in relation to a drug trafficking crime in violation of 18 U.S.C. $\S 924(\mathrm{c})(1) .{ }^{80}$ Subsequently, the Supreme Court held that a defendant violates $\S 924(c)(1)$ only by "active employment" of a firearm in relation to a drug trafficking crime ${ }^{81}$ Because Barron did not actively employ a firearm in his crime, he moved to set aside his conviction. ${ }^{82}$ The government responded that the commercial contract principle of mutual mistake of law required rescission of the entire plea agreement. $^{83}$

The Ninth Circuit disagreed, concluding that

[a] plea bargain is not a commercial exchange. It is an instrument for the enforcement of the criminal law. What is at stake for the defendant is his liberty .... The interests at stake and the judicial context in which they are weighed require that something more than contract law be applied. ${ }^{84}$

The Ninth Circuit then noted that it had decided not to use the doctrine of mutual mistake of law to invalidate plea bargains in past cases before reaching the same conclusion in the case at hand. ${ }^{85}$

While courts have mostly treated criminal defendants the same as or better than parties to normal contracts, there are exceptions. For instance, in Berryhill v. United States ${ }^{86}$ the defendant sought to have his plea agreement voided because, inter alia, it was a contract of adhesion with the government not giving up anything of value. ${ }^{87}$ In response, the United States District Court for the Northern District of Ohio acknowledged that contract law principles apply when a defendant claims that the government breached a plea agreement. ${ }^{88}$ But the court noted that the defendant was trying to rescind portions of his plea agreement and concluded that "application of contract

\footnotetext{
78. Puckett v. United States, 556 U.S. 129, 137 (2009).

79. 172 F.3d 1153 (9th Cir. 1999).

80. Id. at 1155 .

81. Id. at 1156 (quoting Bailey v. United States, 516 U.S. 137, 143 (1995)).

82. $I d$.

83. Id. at 1158 .

84. Id.

85. Id. at $1158-59$.

86. No. 1:15-cv-815, 2016 WL 2610258 (N.D. Ohio May 6, 2016).

87. Id. at *7.

88. Id.
} 
principles to plea agreements does not extend so far as to allow courts to determine whether a contract was formed." 89

Lower courts have also, in some cases, refused to import specific commercial contract law doctrines into plea bargaining. In Anderson v. Wainwright, ${ }^{90}$ the United States District Court for the Middle District of Florida concluded that "a variant of promissory estoppel is not available to prevent an invalid plea proceeding from being a nullity, without legal effect." ${ }^{91}$ Similarly, in State v. Smith, ${ }^{92}$ the Court of Appeals of Ohio denied a defendant relief because he was not able to cite "any authority applying the equitable doctrines of unjust enrichment or promissory estoppel in the context of an attempted plea agreement." ${ }^{93}$ And, in State v. Reed,${ }^{94}$ the Court of Appeals of Washington concluded, "[W]e do not believe the panoply of contract law can be appropriately transported, in toto, into criminal law" and thus doubted that "[c]ontract law doctrines such as severability, impracticability and quantum meruit" apply in the plea-bargaining context. ${ }^{95}$ Case law from jurisdictions around the country has created confusion and inconsistency as to the scope of plea bargains as constitutional contracts.

C. Plea-Bargaining Criminal Defendants Should Be Treated at Least as Well as Parties to Other Government Contracts

If plea agreements are constitutional contracts, we need to address the extent to which contract law informs plea-bargaining law. In other words, to the extent we have established that the Due Process Clause applies to plea bargaining, we next need to establish "what process is due." Clause requires that courts treat pleading defendants at least as well as parties to other contracts, and specifically government contracts.

Again, this should be a relatively palatable proposal, at least in the abstract. As noted, courts across the country have cited the Fourth Circuit's conclusion in Harvey that "both constitutional and supervisory concerns require holding the Government to a greater degree of responsibility than the defendant (or possibly than would

89. Id.

90. 446 F. Supp. 763 (M.D. Fla. 1978).

91. Id. at 765 .

92. No. 2009-CA-81, 2010 WL 5276934 (Ohio Ct. App. Dec. 17, 2010).

93. $I d$. at $* 16 \mathrm{n} .1$.

94. 879 P.2d 1000 (Wash. Ct. App. 1994).

95. Id. at 1002 .

96. See Morrissey v. Brewer, 408 U.S. 471, 481 (1972). 
be either of the parties to commercial contracts) for imprecisions or ambiguities in plea agreements." ${ }^{97}$ Also, as noted, courts sometimes treat criminal defendants better than parties to commercial law contracts by refusing to apply certain commercial contract law doctrines, like mutual mistake of law, that could harm pleading defendants. ${ }^{98}$ Additionally, as the Seventh Circuit concluded in United States $v$. Cook, "A "A defendant who has signed a plea agreement has all the defenses he would have under contract law, plus some."100

However, as noted previously, ${ }^{101}$ and as will be discussed further, ${ }^{102}$ there are certain specific situations where courts treat pleading defendants worse than parties to other contracts, including government contracts. This treatment runs counter to the way that courts typically treat criminal defendants. Courts often use the Due Process Clause to confer greater rights upon criminal defendants than civil litigants. For instance, the Due Process Clause allows criminal defendants to present evidence that civil defendants could not introduce based upon the rape-shield rule. ${ }^{103}$ Moreover, the Due Process Clause is part of the rationale for a criminal defendant's right to present a defense, ${ }^{104}$ which can trump the Federal Rules of Evidence in criminal, but not civil, cases. ${ }^{105}$

Indeed, the common question for courts is the extent to which they need to use the Due Process Clause to extend criminal safeguards to civil and quasi-criminal litigants. In a trilogy of cases, the Supreme Court held that the Due Process Clause gives criminal defendants greater or equal rights than those given to civil litigants and can be used to determine which due process protections in criminal cases need to be imported into civil and quasi-criminal cases.

The keystone case on the issue is Mathews $v$. Eldridge. ${ }^{106}$ In Eldridge, George Eldridge was awarded Social Security disability benefits in June 1968. ${ }^{107}$ In 1972, Eldridge indicated in a questionnaire that his condition had not improved, but the state agency monitoring

97. United States v. Harvey, 791 F.2d 294, 300 (4th Cir. 1986); see also supra text accompanying notes $73-75$.

98. See supra text accompanying notes $78-85$.

99. 406 F.3d 485 (7th Cir. 2005).

100. Id. at $487-88$.

101. See supra text accompanying notes $86-95$.

102. See infra text accompanying notes $246-66,428-50$.

103. See FED. R. EvID. 412(b)(1)(C); State v. Lake, 686 A.2d 510, 515-16 (Conn. App. Ct. 1996) (quoting State v. Cassidy, 489 A.2d 386, 390 (Conn. App. Ct. 1985)).

104. See Crane v. Kentucky, 476 U.S. 683, 690 (1986).

105. See, e.g., Holmes v. South Carolina, 547 U.S. 319, 324 (2006).

106. 424 U.S. 319 (1976).

107. Id. at 323 . 
Eldridge's condition preliminarily determined that his eligibility for benefits had ceased. ${ }^{108}$ The agency informed Eldridge that he could submit additional information pertaining to his condition, but he declined. ${ }^{109}$ Therefore, the agency made a final determination that Eldridge was no longer disabled, and the Social Security Administration ("SSA") accepted that determination. ${ }^{110}$ The SSA notified Eldridge that he had six months to seek reconsideration, but he instead filed a lawsuit challenging the administrative procedures, which did not entitle him to an evidentiary hearing. ${ }^{111}$

That lawsuit eventually reached the Supreme Court, which laid out the three factors it considers in determining the amount of process due to a litigant:

First, the private interest that will be affected by the official action; second, the risk of an erroneous deprivation of such interest through the procedures used, and the probable value, if any, of additional or substitute procedural safeguards; and finally, the Government's interest, including the function involved and the fiscal and administrative burdens that the additional or substitute procedural requirement would entail. ${ }^{112}$

Applying these three factors, the Court concluded that Eldridge was not entitled to a hearing. ${ }^{113}$

In Morrissey v. Brewer ${ }^{114}$ which actually predated Eldridge, the Supreme Court reached a different result using a similar analysis. ${ }^{115}$ In Morrissey, two men were paroled after serving part of their sentences. ${ }^{116}$ Both men were subsequently arrested and had their parole revoked based solely upon parole officers' reports and without parole revocation hearings. ${ }^{117}$ They then appealed, claiming that due process required a hearing. ${ }^{118}$

Those appeals reached the Supreme Court, which began by noting "that the revocation of parole is not part of a criminal prosecution and thus the full panoply of rights due a defendant in

\footnotetext{
108. Id. at 323-24.

109. Id. at 324 .

110. Id.

111. See id. at 324-25.

112. Id. at 335 (citing Goldberg v. Kelly, 397 U.S. 254, 263-71 (1970)).

113. Id. at 349 .

114. 408 U.S. 471 (1972).

115. Id. at 490 .

116. Id. at 472-73.

117. Id.

118. Id. at 474 .
} 
such a proceeding does not apply to parole revocations." ${ }^{119}$ According to the Court, this is because "[p]arole arises after the end of the criminal prosecution, including imposition of sentence." 120

The Court then proceeded to consider the three factors later crystalized in Eldridge. Under factor one, the private interest at stake, the Court found that a parolee has an interest in his continued liberty that is tempered by conditions of his parole that "subject[] him to many restrictions not applicable to other citizens." 121 Therefore, a parolee's private interest is not much weaker than the private interest of a criminal defendant because "the liberty of a parolee, although indeterminate, includes many of the core values of unqualified liberty." 122

Jumping to the third factor, the Court found that the prior conviction and imposition of conditions on a parolee creates "an overwhelming [government] interest in being able to return the individual to imprisonment without the burden of a new adversary criminal trial if in fact he has failed to abide by the conditions of his parole." ${ }^{23}$ That said, under the second factor, the Court concluded that there is a serious risk of erroneous deprivation of a parolee's liberty interest without a hearing because parole boards might otherwise rely upon incomplete or incorrect facts. ${ }^{124}$

Balancing these factors, the Court concluded that the State has no interest in revoking parole without at least some informal procedural guarantees. ${ }^{125}$ On the other hand, the Court found that there is no need for formalism in the parole-revocation context. ${ }^{126}$ Therefore, the Court concluded that due process requires an informal parole revocation hearing to ensure a decision is based upon verified facts. ${ }^{127}$

The Court reached a similar conclusion in its post-Eldridge opinion in Addington v. Texas. ${ }^{128}$ In Addington, Texas applied a preponderance of the evidence standard to civil commitment proceedings, and a committed individual appealed and claimed that the State should be required to prove the need for commitment

119. Id. at 480 (citing Mempa v. Rhay, 389 U.S. 128, 136 (1967)).

120. $I d$.

121. Id. at $481-82$.

122. Id. at 482 .

123. Id. at 483 .

124. Id. at $483-84$.

125. Id. at 484 .

126. Id. at 487.

127. Id. at $487-88$.

128. 441 U.S. 418 (1979). 
beyond a reasonable doubt. ${ }^{129}$ The Supreme Court found that a civil commitment is not as serious as a criminal conviction, ${ }^{130}$ but it also found that such a commitment constitutes a serious deprivation of liberty. ${ }^{131}$ As a result, the Court split the difference between the parties' positions and declared that the State must prove the need for civil commitment by clear and convincing evidence. ${ }^{132}$

Some courts hold that this same standard of proof applies in criminal commitment cases ${ }^{133}$ while other courts require the government to prove the need for criminal commitment beyond a reasonable doubt. ${ }^{134}$ Similarly, many courts find that greater due process protections apply in criminal contempt cases than those that apply in civil contempt cases. ${ }^{135}$

Such differential treatment can also be seen in connection with the one Supreme Court case applying the Eldridge three-factor test to a criminal defendant. In Ake v. Oklahoma ${ }^{136}$ Glen Ake, an indigent defendant, was charged with murdering a couple and injuring their children. ${ }^{137}$ The trial court initially declared Ake incompetent to stand trial but changed its decision after he received an antipsychotic drug. ${ }^{138}$ Defense counsel then indicated that Ake would raise an insanity defense and claimed that the Constitution required the State to arrange for a psychiatrist to examine Ake or provide funds so that the defense could arrange its own examination. ${ }^{139}$ The court disagreed, no examination was done, and Ake was ultimately convicted and sentenced to die. ${ }^{140}$

On appeal, the Supreme Court applied Eldridge's three-factor test to determine whether the State has to provide an indigent defendant with access to psychiatric assistance. ${ }^{141}$ The Court quickly concluded under factor one that " $[\mathrm{t}]$ he private interest in the accuracy

129. Id. at 421 .

130. Id. at 428 .

131. Id. at 425 .

132. Id. at 433 .

133. See, e.g., State v. Rotherham, 923 P.2d 1131, 1148 (N.M. 1996).

134. See, e.g., State v. Paradis, 455 A.2d 1070, 1073 (N.H. 1983).

135. See, e.g., Carlucci v. Piper Aircraft Corp., 775 F.2d 1440, 1451 n.9 (11th Cir. 1985) (citing United States v. Vague, 697 F.2d 805, 808 (7th Cir. 1983)).

136. 470 U.S. 68 (1985).

137. Id. at 70 .

138. Id. at 71-72.

139. See id. at 72

140. See id. at 72-73.

141. See id. at 77 (citing Mathews v. Eldridge, 424 U.S. 319, 335 (1976)). 
of a criminal proceeding that places an individual's life or liberty at risk is almost uniquely compelling."142

Under factor three, the Court turned aside the State's claim that providing psychiatric assistance would be financially burdensome, noting that several states and the federal government already do so without issue. ${ }^{143}$ The Court then found that "it is difficult to identify any interest of the State, other than that in its economy, that weighs against recognition of this right." ${ }^{144}$ This is because "[t]he State's interest in prevailing at trial-unlike that of a private litigant-is necessarily tempered by its interest in the fair and accurate adjudication of criminal cases." ${ }^{\text {M }} 45$ Moreover, "also unlike a private litigant, a State may not legitimately assert an interest in maintenance of a strategic advantage over the defense, if the result of that advantage is to cast a pall on the accuracy of the verdict obtained."

Finally, with regard to factor two, the Court began by noting "the pivotal role that psychiatry has come to play in criminal proceedings." 147 The Court then found that the assistance of a psychiatrist may be crucial for the jury to be able "to make a sensible and educated determination about the mental condition of the defendant at the time of the offense."148 Therefore, the Court concluded that an indigent defendant has a due process right of access to the services of a competent psychiatrist if he can make a threshold showing that his sanity is likely to be a significant factor in his defense. ${ }^{149}$ Notably, courts have not extended this right to civil cases. ${ }^{150}$ For example, in Goetz v. Crosson, ${ }^{151}$ the Second Circuit declined to extend this right to civil cases because "a civil commitment proceeding can in no sense be equated to a criminal prosecution." ${ }^{152}$

All of these cases support the following conclusions: (1) the Due Process Clause gives criminal defendants greater or equal rights than those given to civil litigants, and (2) courts use the Eldridge factors to

142. Id. at 78 .

143. Id. at $78 \&$ n. 4 .

144. Id. at 79 .

145. Id.

146. Id.

147. Id.

148. Id. at 81 .

149. Id. at 83

150. See, e.g., In re Williams, 478 N.E.2d 867, 869 (Ill. App. Ct. 1985) (citing Ake, 470 U.S. at 76-86).

151. 967 F.2d 29 (2d Cir. 1992).

152. Id. at 33 (quoting Addington v. Texas, 441 U.S. 418, 428 (1979)). 
determine when the due process protections in criminal cases need to be imported in whole or in part to civil and quasi-criminal cases. It logically follows from these two conclusions that the Due Process Clause can and should be used, at a minimum, to import each of the protections of civil contract law into the criminal plea-bargaining process. Again, in the abstract, this proposal should not be too controversial, given that courts across the country have found that plea agreements are governed or strongly influenced by contract law, with defendants also afforded the additional protection of the Due Process Clause. ${ }^{153}$

When it gets to specifics, however, it appears that there are at least three significant aspects of the plea-bargaining process where most courts treat pleading criminal defendants worse than their civil counterparts. The final part of this Article explains how importation of a contract law doctrine into the plea-bargaining process would level the playing field and afford pleading defendants additional due process protections.

\section{PleA AgreEMENTS AS CONSTITUTIONAL CONTRACTS AND THE IMPLIED COVENANT OF GOOD FAITH AND FAIR DEALING}

In his dissenting opinion in Ricketts $v$. Adamson, Justice Brennan proposed the idea of plea agreements as constitutional contracts and lamented the fact that the Supreme Court had "yet to address in any comprehensive way the rules of construction appropriate for disputes involving plea agreements." 154 Under this Article's theory of plea agreements as constitutional contracts, the Due Process Clause requires that pleading defendants be treated at least as well as parties to other contracts, and specifically government contracts. At a minimum, this means that every contract defense and rule of construction that applies in the civil contract law context should apply to the extent that it would assist pleading criminal defendants. The remainder of this Article assesses one rule of construction-the implied covenant of good faith and fair dealing-and explains how applying it in the plea-bargaining process would cause significant changes to the way that courts treat (1) substantial assistance motions, (2) Brady disclosures, and (3) prosecutorial presentation of sentencing recommendations.

153. See supra text accompanying notes $57-58$.

154. Ricketts v. Adamson, 483 U.S. 1, 16 (1987) (Brennan, J., dissenting). 


\section{A. Origin of the Implied Covenant of Good Faith and Fair Dealing}

The 1905 opinion of the Court of Appeals of New York in Industrial \& General Trust v. Tod ${ }^{155}$ contains the first significant mention of an implied contractual duty of good faith in American law. ${ }^{156}$ In Tod, New York's highest court concluded that

[n]o one can be made by contract the final judge of his own acts, for the law writes "good faith" into such agreements. No covenant of immunity can be drawn that will protect a person who acts in bad faith, because such a stipulation is against public policy, and the courts will not enforce it. The law requires the exercise of good faith, and, no matter how strong the provision to shield from liability may be, there is no protection unless good faith is observed. ${ }^{157}$

Twenty-eight years later, the New York Court of Appeals fully fleshed out this analysis, creating what is now known as the implied covenant of good faith and fair dealing. In Kirke La Shelle Co. v. Paul Armstrong Co. ${ }^{158}$ playwright Paul Armstrong wrote Alias Jimmy Valentine, a dramatization of O. Henry's novel, $A$ Retrieved Reformation. ${ }^{159}$ Then, in 1921, the Paul Armstrong Company entered into a theatrical licensing agreement with the Kirke La Shelle Company ("La Shelle"), pursuant to which the latter company would receive one-half of the money taken in from theatrical productions of the play. ${ }^{160}$ Subsequently, in 1928, the Paul Armstrong Company sold the motion picture rights to Metro-Goldwyn Mayer Corporation and refused to pay La Shelle royalties connected to the sale. ${ }^{161}$ As a result, La Shelle brought a breach of contract action, claiming that "the contract with Metro-Goldwyn Mayer Corporation was a contract that would affect the production of the play."162

An intermediate appellate court denied La Shelle relief, finding that motion pictures were an unknown quantity at the time of contract formation, meaning that the court could not extend the contract to cover royalties connected to this new medium. ${ }^{163}$ The

155. 73 N.E. 7 (N.Y. 1905).

156. Douglas D. Choe, Note, Vylene Enterprises v. Naugles: Remedies for Franchisor Encroachment, 27 SW. U. L. REV. 353, 363 (1997).

157. Tod, 73 N.E. at 9.

158. 188 N.E. 163 (N.Y. 1933).

159. Id. at 164 .

160. Id.

161. Id.

162. Id. at 166 .

163. Id. at $165-66$. 
state's highest court, however, disagreed, concluding that, by entering into a contract, the parties assumed a fiduciary relationship that created a duty to act with the utmost good faith. ${ }^{164}$ Specifically, the court found that

in every contract there is an implied covenant that neither party shall do anything which will have the effect of destroying or injuring the right of the other party to receive the fruits of the contract, which means that in every contract there exists an implied covenant of good faith and fair dealing. ${ }^{165}$

Applying this implied covenant to the case at hand, the court determined that "there was an implied obligation on the part of the [Paul Armstrong Company] not to render valueless the right conferred by the contract." 166 Therefore, even though the defendant did not violate an express contractual term, it violated the duty created by the implied covenant and breached the contract. ${ }^{167}$

\section{B. The Modern Implied Covenant of Good Faith and Fair Dealing}

Currently, section 1-304 of the Uniform Commercial Code ("U.C.C."), which governs many commercial contracts, states that "[e]very contract or duty within [the U.C.C.] imposes an obligation of good faith in its performance and enforcement." 168 Courts across the country have found that this section is a codification of the implied covenant of good faith and fair dealing. ${ }^{169}$

Similarly, section 205 of the Second Restatement of Contracts, which applies to non-U.C.C. contracts, provides that "[e]very contract imposes upon each party a duty of good faith and fair dealing in its performance and its enforcement." ${ }^{170}$ The Supreme Court recently cited this language in its 2010 opinion in Alabama v. North Carolina. ${ }^{171}$ Almost all states imply a covenant of good faith and fair dealing into every contract. ${ }^{172}$

164. Id. at 166 (citing Underhill v. Schenck, 143 N.E. 773, 778 (N.Y. 1924)).

165. Id. at 167 .

166. Id. at 168 .

167. Id.

168. U.C.C. § 1-304 (AM. LAW INST. \& UNIF. LAW COMM'N 2017).

169. See, e.g., McNally Wellman Co. v. N.Y. State Elec. \& Gas Corp., 63 F.3d 1188, 1198 n.9 (2d Cir. 1995); Donovan v. RRL Corp., 27 P.3d 702, 718 (Cal. 2001).

170. RESTATEMENT (SECOND) OF CONTRACTS $§ 205$ (AM. LAW INST. 1981).

171. 560 U.S. 330, 351 (2010).

172. See, e.g., Wright v. Martek Power, Inc., 314 F. Supp. 2d 1065, 1067 (D. Colo. 2004). 


\section{The Implied Covenant and Government Contracts}

Both the Court of Federal Claims, which hears disputes over government contracts, and the United States Court of Appeals for the Federal Circuit, which reviews those decisions on appeal, have found that the implied covenant of good faith and fair dealing applies to all government contracts. ${ }^{173}$ The Court of Appeals for the Federal Circuit clarified the scope of this covenant in two recent opinions.

First, in Precision Pine \& Timber, Inc. v. United States, ${ }^{174}$ a timber buyer sued the government, claiming that its suspension of fourteen timber sales contracts violated the implied covenant of good faith and fair dealing. ${ }^{175}$ In rejecting this claim in 2010, the Federal Circuit found no breach of the implied covenant because (1) the implied covenant "cannot expand a party's contractual duties beyond those in the express contract or create duties inconsistent with the contract's provisions"; and (2) "one 'benefit' the parties did not contemplate, and which Precision Pine is thus not entitled to under the contracts, is the guarantee of uninterrupted performance." ${ }^{176}$

Second, in 2011, the Court of Federal Claims applied a similar analysis in Metcalf Construction Co. v. United States ${ }^{177}$ to find that the government had not violated the implied covenant by telling a construction contractor during its request for proposals that the soil at a job site had "slight expansion potential" and then stating after the contract took effect (and after additional testing) that the expansion potential was "moderate to high." 178 However, the Federal Circuit reversed in its 2014 opinion in the case, in the process clarifying the scope of the implied covenant. ${ }^{179}$

According to the Federal Circuit, the implied covenant "imposes obligations on both contracting parties that include the duty not to interfere with the other party's performance and not to act so as to destroy the reasonable expectations of the other party regarding the fruits of the contract." 180 Therefore, the terms of a contract help to define the scope of the covenant because they establish the

173. See Nat'l Austl. Bank v. United States, 452 F.3d 1321, 1324 (Fed. Cir. 2006).

174. 596 F.3d 817 (Fed. Cir. 2010).

175. Id. at 820 .

176. Id. at 831 .

177. 102 Fed. Cl. 334 (2011), rev'd, 742 F.3d 984 (Fed. Cir. 2014).

178. Id. at $348-49$.

179. Metcalf Constr. Co. v. United States, 742 F.3d 984, 987 (Fed. Cir. 2014).

180. Id. at 991 (emphasis omitted) (quoting Centex Corp. v. United States, 395 F.3d 1283, 1304 (Fed. Cir. 2005)). 
reasonable expectations of the parties. ${ }^{181}$ But the Federal Circuit rejected the contention that the implied covenant cannot impose duties beyond those contained in express contract provisions; instead, "a breach of the implied duty of good faith and fair dealing does not require a violation of an express provision in the contract." 182

In reaching this conclusion, the court refused to read Precision Pine broadly and instead reaffirmed its prior opinion in Bradley $v$. Chiron Corp. ${ }^{183}$ The Metcalf court emphasized that in Bradley, the Federal Circuit cited a California case holding that "the covenant is implied as a supplement to the express contractual covenants, to prevent a contracting party from engaging in conduct which (while not technically transgressing the express covenants) frustrates the other party's rights to the benefits of the contract." 184 Therefore, the implied covenant allows a government contractor to claim that the government violated the spirit, if not the letter, of the contract. ${ }^{185}$

Because plea agreements are, in effect, government contracts, the Federal Circuit's interpretation of the implied covenant is the best analog for construing the covenant in the plea-bargaining process. This analogy makes even more sense given that parties to traditional contracts receive only the protections of contract law, ${ }^{186}$ while both pleading defendants and government contractors have rights against the government secured by the Due Process Clause. ${ }^{187}$

\section{The Implied Covenant and Plea Agreements}

Given that the Supreme Court has held that plea agreements are essentially contracts, ${ }^{188}$ it is unsurprising that the First, ${ }^{189}$ Second, ${ }^{190}$

181. Id. (quoting Tymshare, Inc. v. Covell, 727 F.2d 1145, 1152 (D.C. Cir. 1984)).

182. Id. at 994 .

183. Id.; 136 F.3d 1317 (Fed. Cir. 1998).

184. Metcalf, 742 F.3d at 994 (first citing Bradley, 136 F.3d at 1326; and then quoting Racine \& Laramie, Ltd. v. Cal. Dep't of Parks \& Recreation, 14 Cal. Rptr. 2d 335, 338 (Cal. Ct. App. 1992)).

185. See Fisher v. United States, 128 Fed. Cl. 780, 787-88 (2016) (concluding that the plaintiff's implied covenant claim was not duplicative of his contract claims).

186. See, e.g., Parker v. BancorpSouth Bank, 253 S.W.3d 918, 924 (Ark. 2007).

187. See, e.g., Lynch v. United States, 292 U.S. 571, 579 (1934) (finding that "[r]ights against the United States arising out of a contract with it are protected by the Fifth Amendment" and that "the due process clause prohibits the United States from annulling" contracts of war risk insurance); ATL, Inc. v. United States, 736 F.2d 677, 683 (Fed. Cir. 1984) (noting that "minimum requirements of due process come into play" with government contracts because bidders "have a liberty interest at stake").

188. Puckett v. United States, 556 U.S. 129, 137 (2009); see also supra text accompanying notes 59-62.

189. United States v. Doe, 170 F.3d 223, 226 (1st Cir. 1999) (Bownes, J., concurring).

190. United States v. Khan, 920 F.2d 1100, 1105 (2d Cir. 1990). 
Third, ${ }^{191}$ Fourth, ${ }^{192}$ Sixth, ${ }^{193}$ Seventh,${ }^{194}$ Eighth, ${ }^{195}$ Ninth, ${ }^{196}$ Tenth, ${ }^{197}$ and D.C. ${ }^{198}$ Circuits have partially incorporated the implied covenant of good faith and fair dealing into plea agreements, as have state supreme courts across the country. ${ }^{199}$ Many of these opinions, however, indicate that a prosecutor can breach the implied covenant of good faith and fair dealing even without violating any express terms of a plea agreement. ${ }^{200}$

For example, in State v. Morrison, ${ }^{201}$ in exchange for Ashley Morrison's guilty plea to a sex crime and acceptance of responsibility, the State agreed not to object to Morrison's request for a suspended sentence. ${ }^{202}$ Thereafter, at the sentencing hearing, the prosecutor told the judge that the version of events given by Morrison in his acceptance of responsibility statement was "disappoint[ing]" and a "fairy tale" in which Morrison "didn't accept any responsibility."203 That said, the prosecutor told the judge that he was not backing out of the plea deal, but he made sure to tell the judge he was under no obligation to adopt the recommendation in the plea agreement. ${ }^{204}$ Ultimately, the judge sentenced Morrison to ten years' incarceration, with five years suspended. ${ }^{205}$ In finding that the prosecutor breached the implied covenant of good faith and fair dealing, the Supreme Court of South Dakota concluded that "[w]hile the agreement was not explicitly reneged, the State impliedly argued for a tougher sentence by voicing its discomfort with a suspended imposition." ${ }^{206}$ In such cases, courts are thus applying the implied covenant of good faith and fair dealing in the same way that they apply it in the civil context.

191. United States v. Isaac, 141 F.3d 477, 482 (3d Cir. 1998).

192. United States v. Levaur, No. 98-4309, 1999 WL 22887, at *2 (4th Cir. Jan. 21, 1999) (unpublished).

193. United States v. Hawkins, 274 F.3d 420, 430-31 (6th Cir. 2001).

194. United States v. Wilson, 390 F.3d 1003, 1012 (7th Cir. 2004).

195. United States v. Crawford, 20 F.3d 933, 935 (8th Cir. 1994).

196. United States v. Carriaga, No. 96-10427, 1997 WL 367829, at *2 (9th Cir. July 2, 1997) (unpublished).

197. Watson v. Wyoming, 83 F. App'x 292, 299 (10th Cir. 2003).

198. United States v. Jones, 58 F.3d 688, 692 (D.C. Cir. 1995).

199. See, e.g., Cole v. State, 922 A.2d 354, 359 (Del. 2005); State v. Sledge, 947 P.2d 1199, 1204 (Wash. 1997).

200. See Metcalf Constr. Co. v. United States, 742 F.3d 984, 991 (Fed. Cir. 2014).

201. 759 N.W.2d 118 (S.D. 2008).

202. Id. at 119 .

203. Id.

204. Id. at 119-20.

205. Id. at 120 .

206. Id. at 121. 


\section{E. Applying the Implied Covenant to Three Key Plea-Bargaining Situations}

Facially, then, it appears as if most courts apply the implied covenant of good faith and fair dealing to the plea-bargaining process in a way that treats criminal defendants at least as well as parties to other contracts, and specifically government contracts. That said, there are three key plea-bargaining situations where most courts have not extended the implied covenant to plea bargaining and have failed to protect pleading defendants. This section identifies these three situations and explains how courts can and should apply the Federal Circuit's interpretation of the implied covenant to produce different results.

\section{Discretionary Government Decisions}

In both government contracts and plea agreements, the government sometimes reserves sole discretion to determine whether the other party has performed in a way that allows for additional benefits. Currently, however, most courts review governmental exercises of that discretion very differently in these two contexts.

\section{a. Substantial Assistance Motions}

Prosecutors often convince defendants to plead guilty based upon the promise to file motions known as substantial assistance motions. Issues often arise when defendants provide some level of assistance that prosecutors deem insufficient to trigger their obligation to file such motions.

\section{i. United States Sentencing Guidelines and Sentencing Ranges}

When a federal judge is sentencing a criminal defendant, she must consult the United States Sentencing Guidelines (the "Guidelines"). ${ }^{207}$ After a federal defendant is convicted, the judge uses the Guidelines to calculate an offense level score and a criminal history score ${ }^{208}$ the judge then plugs those scores into the Guidelines' Sentencing Table to create a sentencing range. ${ }^{209}$ As an example, the Sentencing Table would prescribe a sentencing range of 235 to 293

207. See, e.g., United States v. Crawford, 407 F.3d 1174, 1179 (11th Cir. 2005) (noting that even after the Supreme Court's opinion in United States v. Booker, 543 U.S. 220 (2005), the requirement of consulting the Sentencing Guidelines is inescapable).

208. See, e.g., United States v. Buckner, 9 F.3d 452, 453 (6th Cir. 1993) (tabulating the offense level score and criminal history score).

209. See, e.g., United States v. Thorpe, 191 F.3d 339, 341 (2d Cir. 1999) (using the sentencing table). 
months' incarceration for a defendant with an offense level score of 35 and a criminal history score of $8 .{ }^{210}$ For a defendant with the same criminal history score but an offense level of 30-five levels lowerthe Table would prescribe a range of 135 to 168 months' incarceration. $^{211}$

In 2005, 18 U.S.C. $§ 3553$ (b) provided that federal judges "'shall impose a sentence of the kind, and within the range' established by the Guidelines, subject to departures in specific, limited cases." ${ }^{212}$ In its 2005 opinion in United States v. Booker ${ }^{213}$ the Supreme Court deemed this mandatory Guidelines system unconstitutional and rendered the Guidelines system, and the sentencing range, advisory. ${ }^{214}$ Even after Booker, though, federal judges are still required to consult the applicable sentencing range in imposing sentences. ${ }^{215}$ Moreover, when appellate court judges review federal sentences, they consider the applicable sentencing range as one of seven factors under 18 U.S.C. $§ 3553(a) .{ }^{216}$ Finally, an appellate court is entitled to apply a presumption of reasonableness to a federal sentence that falls within the applicable sentencing range. ${ }^{217}$

\section{ii. Substantial Assistance Motions for Downward Departures}

Given the continuing relevance of the Guidelines' sentencing range, motions for downward departures from that range still have primary importance. According to the Guidelines, a downward departure is a departure that leads to a judge imposing "a sentence less than a sentence that could be imposed under the applicable guideline range or a sentence that is otherwise less than the guideline sentence." ${ }^{218}$ A prosecutor can move for a downward departure under several sections of the Guidelines, including the most frequently used departure: a substantial assistance departure under section $5 \mathrm{~K} 1.1$ of the Guidelines based on assistance given before sentencing. ${ }^{219}$ Section

210. U.S. SENTENCING GuIDELINES MANUAL ch. 5, pt. A (U.S. Sentencing COMM'N 2016).

211. See id.

212. See United States v. Booker, 543 U.S. 220, 234 (2005) (quoting 18 U.S.C. § 3553(b)

(2012), invalidated by United States v. Booker, 543 U.S. 220 (2005)).

213. 543 U.S. 220 (2005).

214. Id. at $245-46$.

215. See, e.g., United States v. Crawford, 407 F.3d 1174, 1179 (11th Cir. 2005).

216. 18 U.S.C. $\$ 3553(a)(4)$ (2012).

217. See Rita v. United States, 551 U.S. 338, 347 (2007).

218. U.S. SENTENCING GUIDELINES MANUAL $§ 1 B 1.1 \mathrm{cmt}$. 1(E) (U.S. SENTENCING COMM'N 2016).

219. See, e.g., Daniel A. Chatham, Note, Playing with Post-Booker Fire: The Dangers of Increased Judicial Discretion in Federal White Collar Sentencing, 32 J. CORP. L. 619, 622 
$5 \mathrm{~K} 1.1$ states in relevant part that "[u]pon motion of the government stating that the defendant has provided substantial assistance in the investigation or prosecution of another person who has committed an offense, the court may depart from the guidelines."220

Prosecutors frequently use section $5 \mathrm{~K} 1.1$ in making plea agreements with defendants; ${ }^{221}$ indeed, the section was created to increase cooperation with law enforcement "and, as a necessary corollary, to maximize the number of times the section would be invoked." "222

After Booker, federal judges must follow a three-step process when a prosecutor files a substantial assistance motion for a downward departure under section 5K1.1: (1) continue to calculate the applicable Guidelines range, (2) formally rule on the motion for a downward departure and state whether they are granting the departure and how that departure effects the Guidelines calculation, and (3) determine whether the reasonableness factors under $\S 3553$ (a) justify a modification of the sentence that resulted from applying steps one and two. ${ }^{223}$

United States $v$. Ireland ${ }^{224}$ provides an illustration of this threestep process. In Ireland, Ian Ireland was charged with various crimes connected to a conspiracy to sell drugs and launder money. ${ }^{225}$ Subsequently, he entered into a plea agreement, pursuant to which he would plead guilty to some of the charges and provide information regarding his co-conspirators in anticipation of the prosecutor filing a section $5 \mathrm{~K} 1.1$ motion. ${ }^{226}$ At the sentencing hearing, the prosecution did indeed make a substantial assistance motion for a five-level downward departure under section 5K1.1.227

Under step one, the court determined Ireland's sentencing range under the Guidelines to be 235 to 293 months' incarceration. ${ }^{228}$ Under

n.20 (2007) ("The most frequently used departure is the substantial assistance motion listed under section 5K1.1.").

220. U.S. Sentencing Guidelines Manual § 5K1.1 (U.S. Sentencing COMM’N 2016).

221. See, e.g., The American College of Trial Lawyers Report and Proposal on Section 5 K1.1 of the United States Sentencing Guidelines, 38 AM. CRIM. L. REV. 1503, 1520 (2001).

222. Bruce M. Selya \& John C. Massaro, The Illustrative Role of Substantial Assistance Departures in Combating Ultra-Uniformity, 35 B.C. L. REV. 799, 810 (1994).

223. United States v. Gunter, 462 F.3d 237, 247 (3d Cir. 2006); see also United States v. Vazquez-Lebron, 582 F.3d 443, 445 (3d Cir. 2009).

224. No. 1:07-CR-249-BLW, 2010 WL 4342324 (D. Idaho Nov. 1, 2010).

225. Id. at $* 1$.

226. See id.

227. Id.

228. Id. 
step two, the court granted the State's motion for a five-level downward departure, which led to a sentencing range of 135 to 168 months. ${ }^{229}$ Finally, under step three, after considering the $\S 3553$ (a) factors, the court imposed a sentence of 108 months, which fell below the Guidelines. ${ }^{230}$

\section{iii. Prosecutorial Discretion over Substantial Assistance Motions}

Only the prosecution, and not the defense, can file a substantial assistance motion for a downward departure under section $5 \mathrm{~K} 1.1$. $^{231}$ Moreover, in the absence of a plea agreement to the contrary, the prosecution has the power, not the duty, to file such a motion and cannot be compelled by the court to file such a motion. ${ }^{232}$

Typically, there are two ways that prosecutors handle section 5K1.1 motions. First, in a minority of cases, the prosecution will make an "unambiguous, unconditional promise to file a downward departure motion." ${ }^{233}$ Such a promise binds the prosecution, meaning that the failure to file such a motion is a breach entitling the defendant to relief. ${ }^{234}$ Second, "[n]ormally, the government retains the discretion to determine whether a defendant's assistance is 'substantial' enough to warrant a $§ 5 \mathrm{~K} 1.1$ motion." 235 Similarly, the government typically retains discretion over whether to file a motion for sentence reduction under Federal Rule of Criminal Procedure 35(b), which covers substantial assistance given by defendants after sentencing. ${ }^{236}$

For instance, in United States v. Aderholt, ${ }^{237}$ the prosecution and defense signed a plea agreement that stated in relevant part:

The United States reserves its option to seek any departure from the applicable sentencing guidelines, pursuant to United States Sentencing Guidelines $\S 5 \mathrm{~K} 1.1$, or Rule $35(\mathrm{~b})$ of the

229. Id.

230. Id.

231. See, e.g., United States v. Knights, 968 F.2d 1483, 1486 (2d Cir. 1992) ("The Supreme Court recently confirmed that only the government may move to downwardly depart on the basis of a defendant's substantial assistance.").

232. See Wade v. United States, 504 U.S. 181, 185 (1992).

233. United States v. Barresse, 115 F.3d 610, 612 (8th Cir. 1997).

234. See id.

235. United States v. Hart, 397 F.3d 643, 646-47 (8th Cir. 2005) (quoting Barresse, 115 F.3d at 612). Many defendants, however, fail to realize that the government retains this discretion. See Brandon J. Lester, Note, System Failure: The Case for Supplanting Negotiation with Mediation in Plea Bargaining, 20 OHIO ST. J. ON DISP. RESOL. 563, 591 n.127 (2005).

236. See FED. R. CRIM. P. 35(b)(1).

237. 87 F.3d 740 (5th Cir. 1996). 
Federal Rules Criminal Procedure, if in the sole discretion of the United States, it is determined that such a departure is appropriate. ${ }^{238}$

\section{iv. Failure to File and Prosecutorial Breach}

Defendants often claim that prosecutors breach plea agreements by failing to file substantial assistance motions, leading to courts having to resolve the claim. In a typical case in which a pleading defendant claims prosecutorial breach, (1) the prosecution and defense sign a plea agreement in which the prosecutor makes the conditional promise to file a section $5 \mathrm{~K} 1.1$ motion if the defendant provides substantial assistance, (2) the defendant provides some level of assistance to the government, (3) the prosecutor unilaterally decides that this assistance does not qualify as substantial assistance, (4) the prosecutor refuses to file a section 5K1.1 motion, and (5) the defendant claims that the prosecution breached the plea agreement. ${ }^{239}$

In its 1992 opinion in Wade v. United States, ${ }^{240}$ the Supreme Court addressed a different but related claim. As the Fourth Circuit Court of Appeals explained in United States $v$. Wade ${ }^{241}$ shortly after he was arrested, "and without the benefit of a plea agreement, Wade began a course of cooperation which provided valuable assistance to the government in other prosecutions, leading to the conviction of coconspirators." 242 After Wade pleaded guilty and the prosecution did not file a section $5 \mathrm{~K} 1.1$ motion, he appealed, claiming that the court should inquire into the government's motives for not filing a motion. $^{243}$

In response, the Supreme Court concluded that district courts have the authority to review the prosecution's failure to file a substantial assistance motion and grant relief if the defendant makes a colorable claim that the failure was because of an unconstitutional motive like discrimination based upon the defendant's race or religion. ${ }^{244}$ The Court, however, noted that Wade had not made such a claim and denied him relief. ${ }^{245}$

238. Id. at 742 .

239. See, e.g., United States v. Garcia-Bonilla, 11 F.3d 45, 46 (5th Cir. 1993).

240. 504 U.S. 181 (1992).

241. 936 F.2d 169 (4th Cir. 1991), aff'd, 504 U.S. 181 (1992).

242. Id. at 170 .

243. Id. at 171 .

244. Wade, 504 U.S. at $185-86$.

245. Id. at 186-87. 
Since Wade, a circuit split has developed over how courts should handle a prosecutor's refusal to file a section 5K1.1 motion after conditionally promising to file one in a plea agreement. A majority of federal circuits that have addressed the issue have concluded that they cannot review the failure to file such a motion for bad faith. ${ }^{246}$ According to these courts, a prosecutor's failure to file is only reviewable if the defendant has claimed racial, religious, or other invidious discrimination. ${ }^{247}$

For instance, in United States v. Garcia-Bonilla, ${ }^{248}$ Jose GarciaBonilla was charged with several drug-related offenses. ${ }^{249}$ The two sides thereafter entered into a plea agreement that contained a clause in which the prosecution conditionally promised to make a section $5 \mathrm{~K} 1.1$ or Rule $35(\mathrm{~b})$ motion "if in its discretion, it is determined that such a departure is appropriate." ${ }^{250}$ Garcia-Bonilla then provided information to the government before sentencing, but the prosecutor ultimately refused to file a section $5 \mathrm{~K} 1.1$ motion, claiming that this information "turned up basically nothing but dead ends." 251

This claim led the district court judge to comment, "Every time I take a plea with the U.S. Attorney's office, there is lots of discussion about $5 \mathrm{~K} 1.1$ at time of taking of the plea and then once in a while a Section 5K1.1 motion is, in fact, filed, but much more often than not, there isn't." ${ }^{252}$ According to the defense, the judge's reaction invited appellate review of the prosecution's possible bad faith in failing to file a section 5K1.1 motion. ${ }^{253}$ The Fifth Circuit disagreed, concluding that the plea agreement did not obligate the prosecution to file a substantial assistance motion. ${ }^{254}$ Instead, Garcia-Bonilla could only be entitled to relief if he could establish that the failure to file was based upon an "unconstitutional motive." 255 Because Garcia-Bonilla made no such allegation, the Fifth Circuit denied him relief. ${ }^{256}$

246. See United States v. Kovac, 23 F. App'x 931, 937 n.6 (10th Cir. 2001) (citing cases from the Fourth, Fifth, Seventh, Eighth, and Eleventh Circuits).

247. See id.

248. 11 F.3d 45 (5th Cir. 1993).

249. Id. at 45 .

250. Id. at 46

251. See Brief for Defendant-Appellant Jose Garcia Bonilla at 10, Garcia-Bonilla, 11

F.3d 45 (No. 93-7124), 1993 WL 13099558, at*10.

252. See id. at 8.

253. See id. at 9.

254. See Garcia-Bonilla, 11 F.3d at 47.

255. See id.

256. See id. 
Some courts have expressed frustration with this approach taken by the majority of circuits. In United States v. Hawkins, ${ }^{257}$ Antwand Hawkins pleaded guilty to two bank robberies in connection with a plea agreement that stated that "determination of whether defendant's conduct rises to the level of 'substantial assistance' will lie with the United States in its sole discretion." ${ }^{258}$ At the time this plea agreement was executed, it was anticipated that Hawkins would be the sole witness against one of his accomplices, David Davis, because another accomplice, Jordell Steen, was deemed incompetent to stand trial and another witness, Mahogany Austin, could not be located. ${ }^{259}$ Ultimately, however, Steen was deemed competent and Austin was located; both eventually testified against Davis. ${ }^{260}$ Hawkins, however, testified as well, and "the AUSA relied heavily on Hawkins's testimony to support the government's case against Davis."261 Nonetheless, the prosecution refused to file a substantial assistance motion. ${ }^{262}$

Before both the district court and the Sixth Circuit during oral arguments, the prosecution admitted "that Hawkins did absolutely everything required of him under the plea agreement." 263 A threejudge panel of the Sixth Circuit thus determined that Hawkins had shown not simply that he supplied substantial assistance but also "that the government's reasons for not filing a downward departure motion were not rationally related to any legitimate government end."264 The panel, however, recognized that prior Sixth Circuit precedent only allowed for review of a failure to file based upon an allegation of an unconstitutional motive. ${ }^{265}$ Therefore, the panel denied Hawkins relief but (unsuccessfully) "urge[d] en banc review of this case" so that the Sixth Circuit could circumscribe its reading of Wade. ${ }^{266}$

A minority of federal circuits have already limited the application of Wade to allow courts to review claims that prosecutors breach plea bargains by failing to file in bad faith. ${ }^{267}$ For example, in

257. 274 F.3d 420 (6th Cir. 2001).

258. Id. at 423 .

259. See id.

260. See id. at 423-24.

261. Id. at 424.

262. See id.

263. See id. at 433 .

264. Id. at 434.

265. See id. at 435 .

266. See id.

267. See United States v. Kovac, 23 Fed. App'x 931, 937 \& n.7 (10th Cir. 2001) (citing cases from the Second, Third, and D.C. Circuits). 
United States v. Isaac, ${ }^{268}$ Rupert Isaac entered into a plea agreement on drug and weapons charges; the agreement contained a clause stating that the government would file a 5K1.1 motion "if the government, in its sole discretion, determines that the defendant has provided substantial assistance in the investigation or prosecution of another person who has committed an offense." 269

Thereafter, Isaac met with law enforcement on a few occasions and provided them information about criminal activity of others, but the prosecution refused to file a section $5 \mathrm{~K} 1.1$ motion, claiming that it had been unable to verify or independently corroborate the information. ${ }^{270}$ Isaac thus moved for an order directing the prosecution to file a section $5 \mathrm{~K} 1.1$ motion but acknowledged that he was not alleging the government's failure to file was based upon constitutionally suspect grounds. ${ }^{271}$ As a result, the district court denied him relief. ${ }^{272}$

On appeal, the Third Circuit reversed. The court acknowledged the existence of Wade and cited it for the proposition that "where the defendant has not entered a plea agreement, it is clear that the prosecutor has almost unreviewable discretion over whether to file a substantial assistance motion." ${ }^{273}$ Isaac, however, had entered into a plea agreement, and the Third Circuit concluded that "it is equally clear that when a defendant has entered into a plea agreement expressly requiring the government to make a $\S 5 \mathrm{~K} 1.1$ motion, a district court has broad powers to enforce the terms of the plea contract." 274

The Third Circuit cited the Supreme Court's opinion in Santobello v. New York and its holding that plea agreements are contractual in nature, meaning that courts apply contract law principles to determine whether they have been satisfied. ${ }^{275}$ The court then applied the implied covenant of good faith and fair dealing, finding that Isaac had a reasonable expectation that the prosecution

268. 141 F.3d 477 (3d Cir. 1998).

269. Id. at 479 .

270. See id. at $479-80$.

271. See id.

272. See id. at 480 .

273. Id. at 481 .

274. Id.

275. See id. at 481-82 (citing Santobello v. New York, 404 U.S. 257, 262 (1971)). The Third Circuit went on to note that " $[\mathrm{t}]$ his court has reasoned from Santobello to the general proposition that "[a]lthough a plea agreement occurs in a criminal context, it remains contractual in nature and is to be analyzed under contract-law principles." $I d$. at 481 (quoting United States v. Moscahlaidis, 868 F.2d 1357, 1361 (3d Cir. 1989)). 
would evaluate his cooperation in good faith. ${ }^{276}$ Therefore, the Third Circuit remanded for an evidentiary hearing to determine whether the government acted in bad faith. ${ }^{277}$

Case law from across the country, including the Federal Circuit, suggests that the Third Circuit acted correctly. It is well established by courts nationwide that when a contract gives one party the power to make discretionary decisions without defined standards, that party must act in accordance with the other party's reasonable expectations and not in an arbitrary or capricious fashion. ${ }^{278}$

In its 2007 opinion in North Star Alaska Housing Corp. v. United States, ${ }^{279}$ the Court of Federal Claims dealt with a situation that was strikingly similar to the situations in Garcia-Bonilla, Hawkins, and Isaac. In North Star, the plaintiff won a government contract and lease to build a 400-unit housing project for soldiers and their families at Fort Wainwright, Alaska. ${ }^{280}$ According to the lease, "the Army, 'at its option' may pay North Star an 'incentive fee' of up to five percent of the maintenance rent for the period of time for which North Star's performance is found by the Army to 'substantially exceed the established standards' of the Lease."281

When the Army did not pay this incentive fee, the plaintiff brought a breach of contract action. ${ }^{282}$ The Army responded that the lease contained no obligation for it to award the incentive fee, meaning that its decision not to reward one was unreviewable. ${ }^{283}$ The Court of Federal Claims disagreed, citing to prior precedent holding "that a range of seemingly unilateral contracting decisions may be set aside if agency officials considered factors that were not relevant, followed improper procedures, or otherwise acted arbitrarily." 284 Specifically, the court noted that, even when the government is given absolute discretion, it must comply with the implied covenant of good

276. See id. at 483 .

277. See id. at 484 .

278. See, e.g., Cavendish Farms, Inc. v. Mathiason Farms, Inc., 792 N.W.2d 500, 506 (N.D. 2010) ("When a contract gives a party discretion the implied covenant of good faith and fair dealing bars that party from exercising that discretion in an arbitrary or unreasonable manner.").

279. 76 Fed. Cl. 158 (2007).

280. See id. at 160 .

281. Id. at 204.

282. See id. at 161.

283. See id. at 204.

284. Id. (citing NI Indus., Inc. v. United States, 841 F.2d 1104, 1106 (Fed. Cir. 1988)); see also George Sollitt Constr. Co. v. United States, 64 Fed. Cl. 229, 247 (2005); RCS Enters. v. United States, 53 Fed. Cl. 303, 309 (2002). 
faith and fair dealing. ${ }^{285}$ Ultimately, the court concluded that the Army breached the implied covenant, ${ }^{286}$ and it has made similar conclusions in other cases. ${ }^{287}$

v. Applying the Implied Covenant to Substantial Assistance Motions

Given that the implied covenant of good faith and fair dealing applies to the government's discretionary decisions in government contracts ${ }^{288}$ there is a good argument under this Article's thesis that the implied covenant should automatically apply to government discretionary decisions in plea agreements, such as the decision to not file a substantial assistance motion. In the absence of such an automatic application, courts would need to consult the three Eldridge factors: (1) the petitioner's private interest, (2) the risk of erroneous deprivation of this interest through the current procedure(s) and the probable value of additional safeguards, and (3) the government's countervailing interest. ${ }^{289}$

The most relevant analog for this analysis is Ake v. Oklahoma, in which the Supreme Court held that an indigent defendant has a due process right of access to the services of a competent psychiatrist if he can make a threshold showing that his sanity is likely to be a factor in his defense. ${ }^{290}$ Under the first factor-the private interest involvedthe Court recognized that " $\mathrm{t}]$ he private interest in the accuracy of a criminal proceeding that places an individual's life or liberty at risk is almost uniquely compelling." 291 This interest is directly implicated when a defendant (1) decides to sign a plea agreement based upon a prosecutor's conditional promise to file a substantial assistance motion, and (2) later claims that the prosecutor acted in bad faith by failing to file such a motion.

The Ake Court found under the third factor-the government's countervailing interest-that any interest the prosecution has in prevailing must be tempered by the interest in a fair and accurate

285. See id.

286. See id.

287. See, e.g., Orange Cove Irrigation Dist. v. United States, 28 Fed. Cl. 790, 800 (1993)

("When one party has the authority to exercise discretion to determine an essential term of a contract ... the covenant of good faith and fair dealing requires that the exercise of that discretion be reasonable." (citing Boone v. Kerr-McGee Oil Indus., 217 F.2d 63, 65 (10th Cir. 1954))).

288. See id.

289. See Mathews v. Eldridge, 424 U.S. 319, 335 (1976).

290. Ake v. Oklahoma, 470 U.S. 68, 83 (1985).

291. Id. at 78 . 
adjudication of criminal cases. ${ }^{292}$ In Santobello, the Court concluded that these same considerations apply to the plea-bargaining process. ${ }^{293}$ Moreover, the Court in Ake refuted the State's claim that granting indigent defendants the right to psychiatric assistance would be unduly burdensome by noting that several jurisdictions already recognize the right without incident. ${ }^{294}$ As noted, a minority of jurisdictions already apply the implied covenant of good faith and fair dealing to allow courts to review refusals to file substantial assistance motions for bad faith. ${ }^{295}$ Therefore, there is not a good argument that bad faith hearings would be unduly burdensome. As the Third Circuit noted in Isaac, "[t]he sole requirement is that the government's position be based on an honest evaluation of the assistance provided and not on considerations extraneous to that assistance."296

Finally, under the second factor-the risk of erroneous deprivation and the probative value of additional safeguards-the Ake Court noted "the pivotal role that psychiatry has come to play in criminal proceedings" and the importance of psychiatric assistance in ensuring that the jury can make a sensible and educated determination about the defendant's mental state. ${ }^{297}$ While this is true, only about one percent of felony defendants raise the insanity defense. ${ }^{298}$ Conversely, about ninety-five percent of criminal cases are resolved by plea agreements, and the most popular downward departure motion included in such agreements is the substantial assistance motion. ${ }^{299}$ Moreover, just as jurors are not able to resolve insanity pleas without psychiatrist participation, courts are unable to determine whether prosecutors breached plea agreements if they are only allowed to review refusals to file substantial assistance motions for unconstitutional motives.

Finally, after balancing all three Eldridge factors, the Ake Court concluded that an indigent defendant is only entitled to psychiatric assistance if he can make the threshold showing that his sanity is likely to be a factor in his defense. ${ }^{300}$ A similar limitation can, and has been, applied in the substantial assistance motion context. In Isaac,

292. Id. at 79

293. See Santobello v. New York, 404 U.S. 257, 261 (1971).

294. Ake, 470 U.S. at 78.

295. See supra text accompanying note 267 .

296. United States v. Isaac, 141 F.3d 477, 484 (3d Cir. 1998).

297. Ake, 470 U.S. at $79,81$.

298. Bonita M. Veysey, Gender Role Incongruence and the Adjudication of Criminal Responsibility, 78 ALB. L. REV. 1087, 1088 (2015).

299. See supra text accompanying notes 3, 219.

300. Ake, 470 U.S. at $82-83$. 
the Third Circuit held that Isaac was entitled to a hearing on whether the government acted in good faith in failing to file a substantial assistance motion only if he made a threshold showing of bad faith. ${ }^{301}$

Only one federal circuit court has applied the Eldridge test to review refusals to file substantial assistance motions. In United States v. Valencia ${ }^{302}$ Sergio Aguera was convicted of conspiring to possess cocaine with intent to distribute after a jury trial. ${ }^{303}$ Subsequent to sentencing, Aguera appealed, claiming that the prosecution failed to file a section 5K1.1 motion despite the fact that he provided the government substantial assistance. ${ }^{304}$

In response, the Seventh Circuit cited Eldridge but concluded that it did not help Aguera because he presupposed a nonexistent right to have the court consider his assistance in sentencing. ${ }^{305}$ Later, the Seventh Circuit applied this same reasoning in United States $v$. Donatiu, ${ }^{306}$ where the defendant did not reach a plea agreement but still ended up pleading guilty. ${ }^{307}$

These conclusions are, of course, correct, as was the Supreme Court's conclusion in Wade: a defendant has no freestanding right to have (1) a prosecutor file a substantial assistance motion, or (2) the judge consider his assistance in sentencing. ${ }^{308}$ But if the prosecution conditionally promises in a plea agreement to file such a motion, the implied covenant of good faith and fair dealing should require that the prosecutor's decision not be made in bad faith. This would place pleading defendants on a level playing field with parties to government contracts, and it would not require overruling Wade. Courts would simply need to find that Wade is inapplicable when a plea agreement is in place.

\section{The Duty to Disclose Material Evidence}

Before entering into a government contract or plea agreement, a company or citizen has an interest in the government disclosing material information that has bearing upon the deal. Currently, however, courts place significantly different obligations upon the government in these two situations.

301. Isaac, $141 \mathrm{~F} .3 \mathrm{~d}$ at 484 .

302. 913 F.2d 378 (7th Cir. 1990).

303. Id. at 380 .

304. Id. at 386

305. Id.

306. 922 F.2d 1331 (7th Cir. 1991).

307. Id. at 1336.

308. See Wade v. United States, 504 U.S. 181, 186-87 (1991). 
a. Brady v. Maryland and Plea Agreements

In Brady v. Maryland, ${ }^{309}$ the Supreme Court concluded that the Due Process Clause places an affirmative obligation on the State to timely disclose material exculpatory evidence to the defense. ${ }^{310}$ The Court later clarified that evidence is material when there is a reasonable probability that its disclosure would have led to a different result, i.e., an acquittal or lesser sentence. ${ }^{311}$ The American Bar Association later followed up on Brady by adopting Model Rule of Professional Conduct 3.8(d), which currently states that a prosecutor must "make timely disclosure to the defense of all evidence or information known to the prosecutor that tends to negate the guilt of the accused or mitigates the offense." 312

There can be a Brady violation based upon the government failing to disclose material substantive evidence, such as a confession by a government's witness that he, and not the defendant, committed the crime at issue. ${ }^{313}$ Moreover, in Giglio v. United States, ${ }^{314}$ the Supreme Court concluded that Brady covers material impeachment evidence that calls into question the credibility of a key witness for the prosecution. ${ }^{315}$ For instance, in Giglio, the prosecution violated Brady by failing to disclose that the defendant's alleged coconspirator and chief witness for the prosecution was testifying pursuant to a promise that he would not be prosecuted if he testified against the defendant. ${ }^{316}$

In its subsequent 2002 opinion in United States v. Ruiz, ${ }^{317}$ the Supreme Court partially determined the relationship between Brady and plea bargaining. In Ruiz, immigration agents found thirty kilograms of marijuana in Angela Ruiz's luggage. ${ }^{318}$ Federal prosecutors thereafter offered Ruiz a "fast track" plea bargain, pursuant to which the government would recommend a two-level downward departure under the Sentencing Guidelines in exchange for Ruiz waiving indictment, trial, and appeal. ${ }^{319}$ The plea deal also required Ruiz to "waiv[e] the right' to receive 'impeachment

309. 373 U.S. 83 (1963).

310. Id. at 87 .

311. United States v. Bagley, 473 U.S. 667, 682 (1985).

312. MODEl RUles OF PROF'L CONDUCT r. 3.8(d) (AM. BAR Ass'N 2017).

313. See, e.g., Scott v. Mullin, 303 F.3d 1222, 1232 (10th Cir. 2002).

314. 405 U.S. 150 (1972).

315. Id. at $154-55$.

316. Id. at 152 .

317. 536 U.S. 622 (2002).

318. Id. at 625 .

319. Id. 
information relating to any informants or other witnesses' as well as the right to receive information supporting any affirmative defense the defendant raises if the case goes to trial." ${ }^{320}$ Because Ruiz would not agree to this last requirement, she rejected the plea deal but later ended up pleading guilty to unlawful drug possession, without any plea agreement. ${ }^{321}$

At sentencing, Ruiz asked the judge to grant her the same twolevel downward departure that she would have received under the plea deal, but the judge instead imposed the standard Guidelines sentence. ${ }^{322}$ On appeal, the Ninth Circuit found that the disputed provision was a Brady waiver and that the right to Brady material cannot be waived without offending the due process requirement that defendants enter plea agreements voluntarily and intelligently. ${ }^{323}$

The Supreme Court, however, disagreed and more generally found that there is no Brady right to material impeachment evidence before pleading guilty for three reasons. ${ }^{324}$ First, the Court concluded that "impeachment information is special in relation to the fairness of a trial, not in respect to whether a plea is voluntary." 325 Second, the Court found that a defendant can voluntarily plead guilty and thus waive several constitutional rights "despite various forms of misapprehension under which a defendant might labor," such as his attorney misjudging the admissibility of a confession or failing to point out a potential defense. ${ }^{326}$ Third, the Court applied the Eldridge factors. Under the first factor-the private interest involved-the Ruiz Court implicitly acknowledged a criminal defendant's compelling interest in obtaining material impeachment evidence. ${ }^{327}$

With regard to the second Eldridge factor-the risk of erroneous deprivation and the probative value of additional safeguards-the Court made two conclusions. First, the proposed plea deal contained a clause obligating the prosecution to provide " any information establishing the factual innocence of the defendant' regardless." 328 According to the Court, "[t]hat fact," plus the safeguards of Rule 11, "diminishes the force of Ruiz's concern that, in the absence of impeachment information, innocent individuals, accused of crimes,

320. Id.

321. Id. at 625-26.

322. Id. at 626.

323. United States v. Ruiz, 241 F.3d 1157, 1167-68 (9th Cir. 2001).

324. Ruiz, 536 U.S. at 629-31.

325. Id. at 629 (emphasis omitted).

326. Id. at 629-30.

327. See id.

328. Id. at 631 . 
will plead guilty." ${ }^{29}$ Second, the Court concluded that the added value of a right to material impeachment evidence would often be "limited, for it depends upon the defendant's independent awareness of the details of the Government's case." 330

Finally, regarding the third factor-the government's countervailing interest-the Court found that requiring pre-plea disclosure of material impeachment evidence could (1) disrupt ongoing investigations by risking premature disclosure of government witness information, (2) force the government to devote more resources to cases prior to plea bargaining, and/or (3) cause the government to cease its heavy reliance on plea bargaining. ${ }^{331}$

As a result of Ruiz, defendants across the country do not have a Brady right to material impeachment evidence prior to plea bargaining. ${ }^{332}$ On the other hand, the Ruiz Court did not resolve the issue of whether defendants have a Brady right to material substantive evidence prior to plea bargaining. ${ }^{333}$ In the absence of Supreme Court guidance, a circuit split has developed over the issue. ${ }^{334}$

The Fifth Circuit is one of the courts that has extended Ruiz to substantive evidence. In United States v. Conroy, ${ }^{335}$ Pamelia Conroy pleaded guilty to fraud charges based upon, inter alia, statements she made to Federal Emergency Management Agency ("FEMA") about her house in the wake of Hurricane Katrina. ${ }^{336}$ After pleading guilty, Conroy learned about a previously undisclosed FBI interview of her friend Sandra Pierce. ${ }^{337}$ According to the FBI report on the interview, Pierce was present for Conroy's call to the FEMA representative, everything Conroy told the representative was accurate, and Conroy left the conversation believing she qualified for FEMA funding. ${ }^{338}$

In finding that there was no Brady violation, the Fifth Circuit rejected Conroy's argument that Ruiz only applies to impeachment

329. Id.

330. Id.

331. Id. at 631-32.

332. See, e.g., Robertson v. Lucas, 753 F.3d 606, 620 (6th Cir. 2014).

333. See McBride v. Bryant, No. 8:12-CV-2895-RMG, 2013 WL 4500050, at*16 (D.S.C. Aug. 21, 2013) ("[T]he Court expressly declined to consider whether this rule also applied to exculpatory substantive evidence.").

334. See Robertson, 753 F.3d at 621 ("We have not yet had occasion to determine whether Ruiz applies to exculpatory Brady material, a question that has caused some disagreement among our sister circuits.").

335. 567 F.3d 174 (5th Cir. 2009).

336. Id. at 176 .

337. Id. at $176-77$.

338. Id. at 177 . 
evidence and not substantive evidence. ${ }^{339}$ According to the court, "Ruiz never makes such a distinction nor can this proposition be implied from its discussion." " 340

In United States v. Ohiri, ${ }^{341}$ the Tenth Circuit took the opposite approach. ${ }^{342}$ In Ohiri, the prosecution charged Emmanuel Ohiri and John Thomas Morris with conspiracy to transport, store, and dispose of hazardous waste in violation of the Resources and Conservation Recovery Act. ${ }^{343}$ Before Morris pleaded guilty, he completed an Acceptance of Responsibility statement, in which he claimed that "Manny Ohiri was not informed of my waste management strategy and techniques in this particular case." ${ }^{344}$

Because the prosecution did not disclose this statement before Ohiri's guilty plea, he later appealed, claiming a Brady violation. ${ }^{345}$ In finding that this claim was potentially viable, the Tenth Circuit determined that the Supreme Court's conclusion with regard to impeachment evidence in Ruiz "did not imply that the government may avoid the consequence of a Brady violation if the defendant accepts an eleventh-hour plea agreement while ignorant of withheld exculpatory evidence in the government's possession." ${ }^{446}$

State courts have similarly split over the issue. For example, in Buffey v. Ballard, ${ }^{347}$ David Ballard pleaded guilty to two counts of sexual assault and one count of robbery pursuant to a plea agreement. ${ }^{348}$ After pleading guilty, Ballard learned that DNA testing had been done in the case, leading to a report concluding: "[A]ssuming there are only two contributors (including [the victim]), Joseph Buffey is excluded as the donor of the seminal fluid identified [from the rape kit] cuttings." ${ }^{449}$ The Supreme Court of Appeals of West Virginia found that the nondisclosure of this DNA testing was a Brady violation, concluding that "Ruiz specifically distinguished impeachment evidence from exculpatory evidence." ${ }^{350}$

339. Id. at 179 .

340. Id.; see also Friedman v. Rehal, 618 F.3d 142, 154 (2d Cir. 2010).

341. 133 F. App'x 555 (10th Cir. 2005).

342. Id. at 556 .

343. Id.

344. Id. at $557-58$.

345. Id. at 558 .

346. Id. at 562; see also McCann v. Mangialardi, 337 F.3d 782, 787 (7th Cir. 2003).

347. 782 S.E.2d 204 (W. Va. 2015).

348. Id. at 206.

349. Id. at 208 .

350. Id. at 213 . 
Conversely, in Walton v. State, ${ }^{351}$ the Court of Appeals of Mississippi found that no such distinction exists. ${ }^{352}$ In Walton, four assailants wearing masks brutally beat a pizza-delivery employee on Halloween night. ${ }^{353}$ Kenny Walton, Jasmond Matthews, Corderal McKnight, and Michael McGee were charged in connection with the assault. ${ }^{354}$ Walton eventually pleaded guilty to the crime without being told that both Matthews and McKnight told police that Desmond Johnson and Nookie Alexander were the other two men involved in the assault. ${ }^{355}$ In rejecting Walton's ensuing Brady claim, the Court of Appeals of Mississippi concluded that Ruiz did not distinguish between impeachment and substantive evidence. ${ }^{356}$

In such cases, defendants frequently seek federal habeas relief after state courts deny their Brady claims. In order to secure habeas relief, however, defendants must show that state courts have violated clearly established federal law as determined by the Supreme Court. ${ }^{357}$ As noted, some circuit courts have found that Ruiz does not distinguish between impeachment and substantive evidence; therefore, federal district courts in these circuits have denied habeas relief to defendants who did not receive material substantive evidence before pleading guilty. ${ }^{358}$ Moreover, both federal circuit courts ${ }^{359}$ and district courts ${ }^{360}$ in circuits that have yet to address the scope of Ruiz have denied habeas relief in such cases due to the circuit split.

\section{b. The Implied Covenant and the Superior Knowledge Doctrine}

Courts have handled the duty to disclose material evidence very differently in the government contract context. In government contracts, it is well established that, "[u]nder the implied duty of good

351. 165 So. 3d 516 (Miss. Ct. App. 2015).

352. Id. at $524-25$.

353. Id. at 518 .

354. Id. at 519.

355. Id.

356. Id. at 524-25.

357. See 28 U.S.C. $\$ 2254(d)(1)(2012)$.

358. See, e.g., Wiand v. United States, No. 3:10-CV-1420-M, 2012 WL 1033623, at*3, *5 (N.D. Tex. Jan. 17, 2012) (denying habeas relief based on the Fifth Circuit's reading of Ruiz).

359. See, e.g., Robertson v. Lucas, 753 F.3d 606, 621-22 (6th Cir. 2014) (finding no clearly established obligation on the government to disclose material substantive evidence due to the circuit split).

360. See, e.g., Carter v. Hobbs, No. 5:10CV00346 JMM/JTR, 2013 WL 1668988, at *6 (E.D. Ark. Mar. 25, 2013) ("Contrary to Petitioner's argument, numerous courts have concluded that there is no federal constitutional right to the disclosure of Brady information prior to the entry of a guilty plea, regardless of whether it is exculpatory evidence, as opposed to impeachment evidence."). 
faith and fair dealing, the Government maintains an implied duty to disclose information fundamental to the preparation of estimates or contract performance." ${ }^{61}$ Therefore, "where the Government possesses special knowledge not shared by the contractor, which is vital to the performance of the contract, the Government has an affirmative duty to disclose such knowledge. It cannot remain silent with impunity." 362 While it is not a fiduciary for its contractors, "the Government-where the balance of knowledge is so clearly on its side-can no more betray a contractor into a ruinous course of action by silence than by the written or spoken word." 363

According to the Federal Circuit, this "superior knowledge" doctrine applies to contracts where

(1) a contractor undertakes to perform without vital knowledge of a fact that affects performance costs or duration; (2) the government was aware the contractor had no knowledge of and had no reason to obtain such information; (3) any contract specification supplied misled the contractor, or did not put it on notice to inquire; and (4) the government failed to provide the relevant information. ${ }^{364}$

This doctrine applied in Miller Elevator Co. v. United States, ${ }^{365}$ where the Miller Elevator Company contracted with the General Services Administration ("GSA") to provide elevator maintenance services for a federal office building in St. Louis. ${ }^{366}$ Later, GSA authorized substantial renovation to the building, resulting in an increase to the amount and extent of work required to maintain the elevators in the building. ${ }^{367}$ Miller responded by claiming that the GSA had breached the contract by failing to disclose that it had anticipated the letting of a $\$ 42$ million contract for renovation of the building before entering into the contract. ${ }^{368}$ The Court of Federal Claims agreed, finding that Miller had satisfied all four elements of the test, meaning that "the Government breached the implied duty of

361. Miller Elevator Co. v. United States, 30 Fed. Cl. 662, 674 (1994).

362. Hardeman-Monier-Hutcherson v. United States, 458 F.2d 1364, 1371-72 (Ct. Cl. 1972) (citing Helene Curtis Indus. v. United States, 312 F.2d 774, 778 (Ct. Cl. 1963)).

363. Helene Curtis Indus. v. United States, 312 F.2d 774, 778 (Ct. Cl. 1963).

364. Petrochem Servs., Inc. v. United States, 837 F.2d 1076, 1079 (Fed. Cir. 1988)

(quoting Am. Shipbuilding Co. v. United States, 654 F.2d 75, 79 (Ct. Cl. 1981)).

365. 30 Fed. Cl. 662 (1994).

366. Id. at 665 .

367. Id.

368. Id. at $665-66$. 
good faith and fair dealing by the nondisclosure of superior knowledge." 369

Similarly, in ASI Constructors, Inc. v. United States, ${ }^{370}$ the Court of Federal Claims denied a motion by the Army Corps of Engineers to dismiss a claim that it violated the implied covenant of good faith and fair dealing by failing to disclose material information regarding site conditions to a government contractor performing work on a dam in Oklahoma ${ }^{371}$ Finally, in Petrochem Services, Inc. v. United States, ${ }^{372}$ the Federal Circuit found that the Navy violated the superior knowledge doctrine by failing to disclose the amount of oil spilled to a government contractor who won a contract to clean an oil spill at the Great Lakes, Illinois, Naval Base. ${ }^{373}$

\section{c. Applying the Implied Covenant to Brady Evidence}

Under this Article's theory of plea agreements as constitutional contracts, courts should incorporate the superior knowledge doctrine into plea agreements and find a Brady violation if (1) a defendant undertakes to perform without vital knowledge of a fact that affects performance, (2) the government was aware the defendant had no knowledge of and had no reason to obtain such information, (3) any discovery supplied misled the defendant or did not put him on notice to inquire, and (4) the government failed to provide the relevant information. All of these factors are already part of the Brady test. To prove a Brady violation, a defendant must establish that (1) he lacked knowledge of material exculpatory evidence, ${ }^{374}$ (2) he could not have obtained the evidence through reasonable diligence, ${ }^{375}$ (3) the government's discovery misled the defendant or did not put him on notice to inquire, ${ }^{376}$ and (4) the government failed to disclose the material exculpatory evidence to the defendant. ${ }^{377}$

369. Id.

370. 129 Fed. Cl. 707 (2016).

371. Id. at $720-21$.

372. 837 F.2d 1076 (Fed. Cir. 1988).

373. Id. at $1077-78$.

374. See, e.g., Patrick v. City of Chicago, 154 F. Supp. 3d 705, 717 (N.D. Ill. 2015).

375. See, e.g., United States v. Prior, 546 F.2d 1254, 1259 (5th Cir. 1977) ("[T]he government is not obliged under Brady to furnish a defendant with information which he already has or, with any reasonable diligence, he can obtain himself.").

376. See, e.g., Ware v. State, 702 A.2d 699, 713-14 (Md. 1997) (finding a Brady violation when the defendant could not have been expected to believe anything other than the government's intentional misrepresentations).

377. See, e.g., Gillispie v. Timmerman-Cooper, 835 F. Supp. 2d 482, 509 (S.D. Ohio 2011) (finding a Brady violation when the government failed to disclose material exculpatory information). 
Given that the implied covenant of good faith and fair dealing requires the government to disclose superior knowledge of material facts before a contractor enters into a government contract, there is a good argument under this Article's thesis that the implied covenant should automatically require the government to disclose material exculpatory evidence to defendants before they enter into plea agreements. ${ }^{378}$ Once again, in the absence of such an automatic application, courts would need to consult the three Eldridge factors.

As noted, the Ruiz Court actually did apply the Eldridge factors in finding that a defendant has no Brady right to material impeachment evidence before pleading guilty. ${ }^{379}$ However, it is important to note that, as was the case in Wade, ${ }^{380}$ there was no plea agreement in Ruiz. ${ }^{381}$ Therefore, there is no reason that Ruiz should bind lower courts in cases where defendants claim that the implied covenant of good faith and fair dealing requires disclosure of material exculpatory evidence before a defendant enters into a plea agreement.

Furthermore, even if Ruiz did apply in this type of case, there are reasons to believe it should be repudiated. First, in July 2009, the ABA Standing Committee on Ethics and Professional Responsibility issued Formal Opinion 09-454, which provided guidance on the scope of the prosecutor's duty to disclose material exculpatory evidence to the defense. ${ }^{382}$ According to Opinion 09-454, the prosecutor has an obligation to disclose material exculpatory evidence "prior to a guilty plea proceeding." 383 While the Standing Committee noted that Rule 3.8 creates a more expansive disclosure obligation than the constitutional duty created by Brady, ${ }^{384}$ Opinion $09-454$ is still persuasive authority that calls the Ruiz holding into question.

Second, as noted, one of the Ruiz Court's primary justifications for not applying Brady to guilty pleas was that a defendant can voluntarily plead guilty and thus waive several constitutional rights "despite various forms of misapprehension under which a defendant might labor," such as his attorney misjudging the admissibility of a

378. See id.

379. See United States v. Ruiz, 536 U.S. 622, 631-32 (2002); see also supra text accompanying notes $327-31$.

380. United States v. Wade, 936 F.2d 169, 170 (4th Cir. 1991), aff'd, 504 U.S. 181 (1992).

381. Ruiz, 536 U.S. at 625.

382. Kevin C. McMunigal, The (Lack of) Enforcement of Prosecutor Disclosure Rules, 38 HOFSTRA L. REV. 847, 850 (2010).

383. ABA Comm. on Ethics \& Prof'l Responsibility, Formal Op. 09-454, at 6 (2009).

384. See id. 
confession or failing to point out a potential defense. ${ }^{385}$ This is no longer the case after Lafler v. Cooper ${ }^{386}$ and Missouri v. Frye, ${ }^{387}$ which held that the right to the effective assistance of counsel applies to the plea-bargaining process. ${ }^{388}$ In its aforementioned opinion in Buffey $v$. Ballard, the Supreme Court of Appeals of West Virginia noted that the Court's conclusions in Lafler and Frye "suggest that the assertion that Brady is a 'trial right' will not preclude it from being applied during plea bargaining." 389

There are also reasons to question the Court's decision in Ruiz under the Eldridge factors. Under the first factor-the private interest at stake-it is clear that a criminal defendant has a uniquely compelling interest in not being deprived of life or liberty without due process of law. ${ }^{390}$

With regard to the second factor-the risk of erroneous deprivation and the probative value of additional safeguards-the Ruiz Court first found that the risk of erroneous deprivation was mitigated by a clause in the proposed plea agreement obligating the prosecution to provide "any information establishing the factual innocence of the defendant." ${ }^{391}$ This conclusion, however, ignores the fact that Brady evidence is, by definition, evidence that creates the reasonable probability of a different outcome at trial, principally a "not guilty" verdict instead of a "guilty" verdict. ${ }^{392}$ Under the plea clause in Ruiz, a defendant would seemingly be entitled to evidence of an alternate suspect's confession but would not be entitled to evidence that the government's key witness was legally blind, would be testifying pursuant to a favorable plea deal, or was out of town on the night of the crime.

385. Ruiz, 536 U.S. at 630.

386. 566 U.S. 156 (2012).

387. 566 U.S. 134 (2012).

388. See id. at 134, 143; Lafler, 566 U.S. at 162.

389. Buffey v. Ballard, 782 S.E.2d 204, 212 (W. Va. 2015) (quoting Michael N. Petegorsky, Plea Bargaining in the Dark: The Duty to Disclose Exculpatory Brady Evidence During Plea Bargaining, 81 FORDHAM L. REV. 3599, 3467 (2013)); see also Gladwell v. DeCamp, No. 3:10-cv-00061-BR, 2012 WL 5182804, at *7 n.5 (D. Or. Oct. 16, 2012) ("In light of the Supreme Court's recent expansion of ineffective assistance of counsel principles to the plea agreement stage in Missouri v. Frye and Lafler v. Cooper, however, the continued effect of Ruiz may well be called into question." (citations omitted)).

390. Ake v. Oklahoma, 470 U.S. 68, 78 (1985).

391. United States v. Ruiz, 536 U.S. 622, 631 (2002).

392. See United States v. Bagley, 473 U.S. 667, 678, 682 (1985) (determining the materiality of Brady evidence). 
Essentially without explanation, the Ruiz Court's opinion prioritizes evidence that strengthens a defendant's case for his innocence over evidence that weakens the government's case for guilt. Such a forced dichotomy seems at odds with Model Rule 3.8(d), which, as noted, obligates the prosecutor to "make timely disclosure to the defense of all evidence or information known to the prosecutor that tends to negate the guilt of the accused." 393 Also, despite the plea clause in Ruiz, it is clear that at least some courts, such as the Court of Appeals of Mississippi in Walton v. State, have found that Brady does not apply in the plea-bargaining context even when the evidence at issue is evidence of innocence. ${ }^{394}$

Moreover, the Ruiz Court seemingly lacked support for its conclusion that the safeguards of Rule 11 "diminish[] the force of Ruiz's concern that, in the absence of impeachment information, innocent individuals, accused of crimes, will plead guilty." ${ }^{395}$ As noted, Rule 11 requires a judge to address a defendant personally to ensure that his plea is knowing, voluntary, and intelligent. ${ }^{396}$ It is unclear how this safeguard protects a defendant who is pleading guilty because the government has withheld evidence of a key weakness in its case.

The Ruiz Court also argued that the value of the Brady safeguard in the plea-bargaining context would often be "limited, for it depends upon the defendant's independent awareness of the details of the Government's case." ${ }^{397}$ But it is hard to imagine when this would be true for either substantive or impeachment evidence. In the case of forensic evidence, such as a DNA test excluding the defendant as the source of physical evidence in the case, the probative value of the evidence would be immediately apparent. In cases of exculpatory statements, such as someone else telling the police, "The defendant did not commit the crime," "Joe Doe committed the crime," or "I committed the crime," again the probative value would be clear. And, in the impeachment context, while a defendant might not know all of the contours of the government's case, he would certainly recognize the importance of an eyewitness suffering an infirmity such as legal

393. Model Rules of PROF'L CONDuCT r. 3.8(d) (AM. BAR Ass'N 2017).

394. See supra text accompanying notes $351-56$.

395. Ruiz, 536 U.S. at 631 (citing McCarthy v. United States, 394 U.S. 459, 465-67 (1969)).

396. See supra text accompanying note 12 .

397. Ruiz, 536 U.S. at 630-31 ("The degree of help that impeachment information can provide will depend on the defendant's own independent knowledge of the prosecution's potential case ...."). 
blindness or an accomplice having a history of crimes of dishonesty or an agreement to testify based upon a favorable plea deal.

Finally, regarding the third factor-the government's countervailing interest-the Ruiz Court began by noting that requiring disclosure of material impeachment evidence before guilty pleas "risks premature disclosure of Government witness information, which ... could 'disrupt ongoing investigations' and expose prospective witnesses to serious harm." "398 As support for this conclusion, the Court cited to the Jencks Act, Federal Rule of Criminal Procedure 16, and 18 U.S.C. $\$ 3432$, all of which allow for "late" disclosure of certain witness information. ${ }^{399}$ The Ruiz Court, however, failed to acknowledge that (1) the early disclosure requirements of Brady typically trump the later disclosure requirements of these other laws and rules, ${ }^{400}$ and (2) the government can request deferral of early production if it has concerns in a particular case. ${ }^{401}$ It is unclear why the prosecution could not employ a similar deferral procedure before plea hearings as it currently employs before trials to quell the identified risks.

Instead of reaching such a resolution, however, the Ruiz Court concluded that requiring disclosure of material impeachment evidence before guilty pleas could alternately force the government to devote more resources to plea bargaining or abandon its heavy reliance on plea bargaining. ${ }^{402}$ Given that several states already require disclosure of some Brady material during plea bargaining, the Ake opinion would suggest that this fear is misplaced. ${ }^{403}$ Perhaps more importantly, the Ruiz Court's conclusion is fundamentally at odds with the Court's prior opinion in United States v. Mezzanatto. ${ }^{404}$

Typically, Federal Rule of Evidence 410 precludes the prosecution from introducing any statements the defendant made during plea bargaining at trial. ${ }^{405}$ But, in Mezzanatto, as a precondition to plea bargaining, the prosecution forced the defendant to sign a waiver indicating that any statements he made during plea discussions could be used to impeach him in the event his case went to

398. Id. at $631-32$.

399. Id. at 632 (first citing 18 U.S.C. $§ 3432$ (2012); then citing id. $\S 3500$ (Jencks Act); and then citing FED. R. CRIM. P. 16(a)(2)).

400. See, e.g., United States v. Jacobs, 650 F. Supp. 2d 160, 171 (D. Conn. 2009).

401. See, e.g., United States v. Lujan, 530 F. Supp. 2d 1224, 1257 (D.N.M. 2008).

402. Ruiz, 536 U.S. at 632.

403. See supra text accompanying note 143 .

404. 513 U.S. 196 (1995).

405. See FED. R. EVID. 410. 
trial. ${ }^{406}$ The defendant later claimed that Rule 410 was not waivable and that allowing for waivers could "bring plea bargaining to a grinding halt." ${ }^{407}$

In response, the Mezzanatto Court raised some of the same concerns that the Ruiz Court would later raise about how plea bargaining can complicate ongoing investigations, especially given limited governmental resources. ${ }^{408}$ But this did not lead the Court to conclude that Rule 410 should be repealed or that the defendant's countervailing interest should make the Rule nonwaivable. Instead, the Court found that "[a] sounder way to encourage settlement is to permit the interested parties to enter into knowing and voluntary negotiations without any arbitrary limits on their bargaining chips." 409 As a result, Rule 410 applies to plea bargaining but is waivable. If the prosecution has a relatively strong case, the defendant might sign a waiver to get to the plea-bargaining table; if the prosecution has a relatively weak case, the defendant might refuse to sign a waiver and force the prosecution to plea bargain without one.

The Mezzanatto solution seems equally applicable to the Ruiz scenario. Indeed, the Court in Ruiz easily could have found that the Brady waiver in the case it was reviewing was valid without reaching the sweeping conclusion that Brady doesn't apply in whole or in part to the plea-bargaining process. Both the superior knowledge doctrine and Mezzanatto suggest that the Brady doctrine should apply in the plea-bargaining context, with the parties able to negotiate a possible Brady waiver.

Applying the Brady doctrine to plea bargaining based on the implied covenant would place defendants in the same position as a government contractor. They could either negotiate away their right to material exculpatory evidence or enter into plea agreements only after learning about the existence of such evidence from the party with superior knowledge.

\section{The Affirmative Duty to Cooperate}

A company or citizen who enters into a government contract or plea agreement has an interest in the government affirmatively cooperating in a manner consistent with the reasonable expectations

406. Mezzanatto, 513 U.S. at 198.

407. Id. at 209.

408. See id. at 207.

409. Id. at 208. 
of the party. Most courts, however, currently place significantly different obligations upon the government in these two situations.

\section{a. Benchimol and the Duty Not to Undermine}

In United States v. Benchimol, ${ }^{410}$ John Benchimol, a minor, was charged with one count of mail fraud after allegedly using false names and information to obtain credit cards. ${ }^{411}$ Benchimol entered into a sentencing recommendation agreement, which required the government to recommend probation with restitution in exchange for Benchimol's guilty plea. ${ }^{412}$ The presentence report presented at the sentencing hearing, however, incorrectly stated that the government would remain silent regarding the proposed sentence. ${ }^{413}$ As a result, when the prosecutor initially said nothing, defense counsel informed the judge that the government had in fact agreed to recommend probation with restitution. ${ }^{414}$ In response, the prosecutor spoke his only words regarding the government's recommendation: "That is an accurate representation." 415 The judge subsequently sentenced Benchimol to six years of treatment and supervision under the Youth Corrections Act. ${ }^{416}$

Benchimol thereafter moved to withdraw his plea or have his sentence vacated, claiming that the government had breached the plea agreement. ${ }^{417}$ The district court denied his motion, but the Ninth Circuit found on appeal that the government can breach a plea agreement by merely making "[a] perfunctory statement of the recommendation," which "can easily leave the impression that the government is unconvinced that the recommendation is appropriate or even that it tacitly disfavors the recommendation." ${ }^{418}$ Finding that the prosecutor made such a perfunctory statement in the case at hand, the Ninth Circuit ruled that there was a breach, concluding "that when the government undertakes to recommend a sentence pursuant to a plea bargain, it has the duty to state its recommendation clearly to the sentencing judge and to express the justification for it."419

410. 738 F.2d 1001 (9th Cir. 1984), rev'd, 471 U.S. 453 (1985).

411. Id. at 1002 .

412. Id.

413. Id.

414. Id.

415. Id.

416. United States v. Benchimol, 471 U.S. 453, 453 (1985).

417. Id.

418. Benchimol, 738 F.2d at 1002.

419. Id. 
The Ninth Circuit bolstered its finding by citing two other federal circuit court opinions. In the Fifth Circuit case United States $v$. Grandinett $^{420}$ the prosecutor said the following to the judge about the recommendation in the plea agreement: "I'm not too sure of the legality of it nor the propriety, but none the less it is there."421 Similarly, in the Fourth Circuit case United States v. Brown ${ }^{422}$ the prosecutor said the following to the judge about the recommendation in a plea deal: "Well, Your Honor, I do have some problems with that, anyhow, but that is the way I understand it." ${ }^{423}$ Both courts concluded that these comments breached the respective plea agreements. ${ }^{424}$

In his dissenting opinion in Benchimol, however, Judge John Wallace distinguished Grandinetti and Brown as cases where "the prosecutors expressed open distaste for the plea bargains" as opposed to lukewarm support. ${ }^{425}$ According to Judge Wallace, neither the Supreme Court Rules nor the Model Code of Professional Responsibility imposes a duty of zeal on prosecutors in "fulfilling a bargain, nor could they" because "[t]he defendant is not the prosecutor's client." ${ }^{\prime 26}$

In its 1985 opinion in United States v. Benchimol, ${ }^{427}$ the Supreme Court agreed with Judge Wallace's dissent in a per curiam opinion. ${ }^{428}$ The Court began by noting that the government in a given case might agree as part of a plea deal to "enthusiastically" recommend a certain sentence or explain the reasons behind its recommendation. ${ }^{429}$ It then found, though, that the parties had struck no such bargain in the present case and that the Ninth Circuit had instead implied an obligation to enthusiastically recommend a sentence based upon the government's promise to recommend a particular sentence. ${ }^{430}$ The Court then rejected this reasoning, concluding that Federal Rule of Criminal Procedure 11 "does not suggest ... such implied-in-law terms as were read into this agreement by the Court of Appeals." 431

420. 564 F.2d 723 (5th Cir. 1977).

421. Id. at 725 .

422. 500 F.2d 375 (4th Cir. 1974).

423. Id. at 377.

424. Grandinetti, 564 F.2d at 727; Brown, 500 F.2d at 378.

425. United States v. Benchimol, 738 F.2d 1001, 1004 (9th Cir. 1984) (Wallace, J., dissenting), rev'd, 471 U.S. 453 (1985).

426. $I d$.

427. 471 U.S. 453 (1985).

428. See id.

429. Id. at 455 .

430. Id.

431. Id. 
Finally, the Court agreed with Judge Wallace's determination that Grandinetti and Brown were inapposite because the prosecutors expressed reservations about the plea agreements in those cases instead of merely offering tepid support, as was the case in Benchimol. ${ }^{432}$

Since Benchimol, most courts have agreed with its dichotomy and held that a prosecutor may express less than enthusiastic support for a plea agreement as long as the prosecutor "does not undermine her own promised sentencing recommendation by expressing her personal reservations at the sentencing hearing." ${ }^{433}$ For instance, in United States $v$. Hand, ${ }^{434}$ the prosecutor agreed to recommend a twolevel reduction in sentencing level based upon the defendant's minor participation in a drug crime. ${ }^{435}$ At the sentencing hearing, the prosecutor said the following:

Regarding role in the offense, we again recommend that this defendant receive a reduction for having a minor role in the offense. That was my assessment at that time. The court's well aware of the facts in this case and can make its own conclusion. We've agreed to recommend that, however. ${ }^{436}$

Hand later appealed, arguing "that the government violated the spirit, if not the letter, of the plea agreement." ${ }^{437}$ In finding that this statement did not breach the plea agreement, the Tenth Circuit cited Benchimol to conclude that, "[a]lthough the prosecutor's simple statement that the court could reach its own conclusion was unnecessary and probably imprudent under the circumstances, it was not tantamount to an argument that the recommendation should be disregarded or that the reduction would be improper." 438

In turn, the Seventh Circuit cited this language from Hand in United States $v$. Jimenez, ${ }^{439}$ a case in which the prosecutor actually made an unconditional promise to file a section $5 \mathrm{~K} 1.1$ motion for a

432. Id. at 456 .

433. State v. Shaffer, 239 P.3d 285, 292 (Utah Ct. App. 2010); see also Kevin Arns, Note, Not All Plea Breaches Are Equal: Examining Heredia's Extension of Implicit Breach Analysis, 100 Nw. U. L. REV. 617, 629 (2016) (noting that circuit courts generally allow prosecutors to express less than enthusiastic support for a sentencing recommendation as long as they do not undermine that recommendation).

434. 913 F.2d 854 (10th Cir. 1990).

435. Id. at 855 .

436. Id. at 856 .

437. Id.

438. Id. at 857 .

439. 992 F.2d 131 (7th Cir. 1993). 
downward departure. ${ }^{440}$ The prosecutor completed, but did not file, a 5K1.1 motion, but he did make a brief oral request for a downward departure at the sentencing hearing. ${ }^{441}$ The judge did not grant a downward departure, stating that "[t]he government's ... apparent oral motion for 5(k)1.1 departure is denied. It hasn't been properly substantiated." ${ }^{442}$ At this point, the prosecutor filed the $5 \mathrm{~K} 1.1$ motion, prompting the judge to respond "the motion is filed and denied." ${ }^{443}$ In concluding that the prosecutor had not breached the plea agreement, the court found the last-minute filing was "probably imprudent under the circumstances" but "did not undermine the recommendation that the government made to the court." 444

Some courts have even found that a prosecutor does not need to make any oral recommendation at a sentencing hearing. In United States v. Cates, ${ }^{445}$ Edward Cates agreed to plead guilty to one count of wire fraud and four counts of bank robbery in exchange for the prosecutor promising to "recommend at sentencing" a ten-year cap on any sentence. ${ }^{46}$ At the sentencing hearing, the prosecutor did not orally make this recommendation and impliedly argued for a "strict, yet indeterminate, term of imprisonment" by telling the judge:

It seems to me that Mr. Cates has in his head, in the words of Auden, "I like committing crimes. It seems the system likes forgiving them. Really, the world is admirably arranged." ... $[\mathrm{P}]$ rotection of the public is probably the only consideration that can be served at this stage. ${ }^{447}$

The Fifth Circuit found that the prosecutor's actions did not violate the plea agreement. While the prosecutor did not orally make the promised recommendation, the court found "that the recommended ten-year cap was prominently featured in all three documents before the sentencing court": the plea agreement, the sentencing memorandum, and the presentence report. ${ }^{448}$ Further, with regard to the prosecutor's statement, the court concluded that, "[i]n ... light of Benchimol, we cannot hold that the government's promise

440. Id. at 132 .

441. Id. at 133 .

442. Id.

443. Id.

444. Id. at 135 (quoting United States v. Hand, 913 F.2d 854, 857 (10th Cir. 1990)).

445. 952 F.2d 149 (5th Cir. 1992).

446. Id. at 150,153 .

447. Id. at 152 .

448. Id. at 153 . 
in this case ... precluded the prosecutor from arguing for a strict, yet indeterminate, term of imprisonment." 449

Conversely, courts in a handful of states have placed a greater obligation on prosecutors. For example, in State v. Wills ${ }^{450}$ Daniel Wills agreed to plead guilty to two counts of sexual misconduct in exchange for the prosecutor dropping a third charge and recommending "unified terms of fifteen years, with minimum periods of confinement of three years." ${ }^{451}$ At sentencing, the prosecutor commented that "[w]hat he did to these two little ones is just completely horrendous and almost unthinkable. And I think, at a very minimum, he should get three years fixed followed by twelve indeterminate for fifteen. I think the state is showing great restraint by only recommending that sentence. $" 452$

In deciding that the prosecutor breached the plea agreement, the Supreme Court of Idaho noted Benchimol's holding but found that "Wills was entitled to have the prosecutor's conduct conform to what Wills reasonably understood to be the bargain." 453 The court then cited Webster's New International Dictionary, which "defines 'recommend' as 'to mention or introduce as being worthy of acceptance, use, or trial."'454 According to the court, the prosecutor's comments did not endorse the agreement as one the judge should accept and therefore violated that agreement. ${ }^{455}$

In its opinion in State v. Foster, ${ }^{456}$ the Court of Appeals of Kansas reached the same result when the prosecutor simply said the following at sentencing: "The State did agree to probation in this case and that is our recommendation." ${ }^{457}$ In making this conclusion, the court cited to the implied covenant of good faith and fair dealing and found that it supported the conclusion that a prosecutor must take special care to fulfill "any term of a plea agreement that has induced the defendant to give up constitutionally protected rights and plead to a crime." ${ }^{458}$ Similarly, in State v. Lopez, ${ }^{459}$ the Supreme Court of Iowa held that "[o]ur precedent makes clear the prosecutor must do more

449. Id.

450. 102 P.3d 380 (Idaho Ct. App. 2004).

451. Id. at 381 .

452. Id.

453. Id. at 383 .

454. Id. (quoting WEBSTER's NEW INTERNATIONAL DICTIONARY 1897 (3d ed. 1993)).

455. Id.

456. 180 P.3d 1074 (Kan. 2008).

457. Id. at 1076, 1077.

458. Id. at 1079 .

459. 872 N.W.2d 159 (Iowa 2015). 
than merely recite the plea recommendation; the prosecutor must 'indicate to the court that the recommended sentence[] [is] supported by the State and worthy of the court's acceptance." 460

\section{b. The Duty to Cooperate and Not to Hinder}

As noted previously, section 205 of the Second Restatement of Contracts defines the implied covenant of good faith and fair dealing. ${ }^{461}$ Comment $d$ to section 205 states that

bad faith may be overt or may consist of inaction, and fair dealing may require more than honesty. A complete catalogue of types of bad faith is impossible, but the following types are among those which have been recognized in judicial decisions: evasion of the spirit of the bargain, lack of diligence and slacking off, willful rendering of imperfect performance, abuse of a power to specify terms, and interference with or failure to cooperate in the other party's performance. ${ }^{462}$

Courts have interpreted this comment and the implied covenant of good faith and fair dealing to encompass both the duty to cooperate and the duty not to hinder. As the Court of Federal Claims noted in Tecom, Inc. v. United States, ${ }^{463}$ "while '[t]he implied duties to cooperate and not to hinder are two separate, albeit related, implied duties,' they appear to be 'disparate aspects' of the overarching duty of good faith and fair dealing." 464

The duty not to hinder is the obligation not to willfully or negligently interfere with the other party's performance of the contract. ${ }^{465}$ This duty exists "because it is rarely possible to anticipate in contract language every possible action or omission by a party that undermines the bargain." ${ }^{466}$ For instance, in Local America Bank of Tulsa v. United States, ${ }^{467}$ the Court of Federal Claims found that Congress breached the duty not to hinder by repealing a tax

460. Id. at 179 (quoting State v. Bearse, 748 N.W.2d 211, 216 (Iowa 2008)).

461. See supra text accompanying note 170 .

462. RESTATEMENT (SECOND) OF CONTRACTS $§ 205 \mathrm{cmt}$. d (AM. LAW INST. 1981).

463. 66 Fed. Cl. 736 (2005).

464. Id. at 769 (citations omitted) (first quoting Precision Pine \& Timber, Inc. v. United States, 50 Fed. Cl. 35, 59 n.31 (2001); and then quoting Walter Dawgie Ski Corp. v. United States, 30 Fed. Cl. 115, 130 (1993)).

465. Id. at 770 (quoting Peter Kiewit Sons' Co. v. United States, 151 F. Supp. 726, 731 (Ct. Cl. 1957)).

466. Metcalf Constr. Co. v. United States, 742 F.3d 984, 991 (Fed. Cir. 2014).

467. 52 Fed. Cl. 184 (2002). 
deduction that a bank planned to use after contracting with the government to take over failing savings and loan institutions. ${ }^{468}$

The duty to cooperate supplements this duty not to hinder and requires that the government do whatever is necessary to enable the contractor to perform. ${ }^{469}$ Courts have found that the government violates the duty to cooperate by engaging in behavior such as responding to a contractor's requests in an evasive or untimely manner or failing to provide reasonable assistance at a contractor's request. ${ }^{470}$ For example, in D'Andrea Bros. LLC v. United States, ${ }^{471}$ a contractor entered into an agreement with the United States Army Natick Soldier Research, Development, and Engineering Center ("Natick") to commercialize energy bars called "HooAH! Bars" that had been developed by Natick and were included in the operational rations provided to soldiers. ${ }^{472}$ The contract stated that Natick would help the contractor test and improve the bar. ${ }^{473}$

Natick complied with the express terms of the contract but also "bad mouthed" the contractor and developed "its own bar within the military feeding community." 474 The Court of Federal Claims, however, rejected the contractor's claim that Natick violated the duty not to hinder because (1) this "bad mouthing" was only done internally with military personnel and (2) Natick did not produce its new bar for the commercial market. ${ }^{475}$

Conversely, the court found that Natick did fail "to cooperate with [the contractor] during a significant period of the [contract] term" by (1) changing the internal name of the HooAh! Bar to the "First Strike" bar and (2) failing to communicate with the contractor through their "key contacts" for a period of months. ${ }^{476}$ According to the court, "the government's actions destroyed plaintiff's reasonable expectation that the parties would work cooperatively to develop and commercialize the HooAH! energy bar that would be the same or

468. Id. at $185,191-92$.

469. See Axion Corp. v. United States, 75 Fed. Cl. 99, 120-21 (2007) (quoting Orlosky Inc. v. United States, 68 Fed. Cl. 296, 311 (2005)).

470. Tecom, Inc., 66 Fed. Cl. at 770; see, e.g., Lewis-Nicholson, Inc. v. United States, 550 F.2d 26, 32 (Ct. Cl. 1977) (finding that the Bureau of Public Roads breached the duty to cooperate by not accommodating a contractor's accelerated performance to ensure completion of a project before winter weather).

471. 109 Fed. Cl. 243 (2013).

472. Id. at 246-47.

473. Id. at 247 .

474. Id. at 250-52, 255 .

475. Id. at $260 \mathrm{n} .15$.

476. Id. at $247,259-61$. 
similar to the bars available in military rations." 477 Therefore, the implied covenant of good faith and fair dealing covers the affirmative duty to cooperate in addition to the duty not to hinder.

\section{c. Applying the Implied Covenant to Presentation of Sentencing} Recommendations

The foregoing analysis makes clear that the implied covenant of good faith and fair dealing in the government contract context contains both "the affirmative duty to cooperate ... and the negative obligation not to hinder or delay performance" by engaging in conduct that undermines the bargain. ${ }^{478}$ Under Benchimol and its progeny, courts have applied the duty not to hinder to plea agreements by concluding that a prosecutor cannot express personal reservations about plea agreements in a way that undermines her promised sentencing recommendation. ${ }^{479}$

Arguably, however, the vast majority of courts have not applied the duty to cooperate in the plea-bargaining context. Since Benchimol, most courts have rejected claims that a prosecutor can breach a plea agreement based upon behavior such as offering tepid support for a sentencing recommendation, failing to provide the reason(s) for the recommendation, and even conveying information to the judge that could cause a harsher sentence. ${ }^{480}$

In D'Andrea, the Court of Federal Claims found that Natick breached the duty to cooperate by failing to collaborate with a contractor so that it could commercialize the HooAh! Bar in a manner consistent with the contractor's reasonable expectations. ${ }^{481}$ The comparable question in the plea-bargaining context is whether a pleading defendant reasonably expects that the prosecutor will make his sentencing recommendation "clear[] to the sentencing judge and to express the justification for it." 482 While the Ninth Circuit majority in Benchimol answered this question in the affirmative, the dissent disagreed, concluding that neither the Federal Rules nor the Model Code of Professional Responsibility imposes a duty of zeal on prosecutors in "fulfilling a bargain, nor could they" because "[t]he

477. Id. at 260 .

478. Universal Shelters of Am., Inc. v. United States, 87 Fed. Cl. 127, 145 (2009).

479. See supra text accompanying note 433.

480. See supra text accompanying notes $432-44$.

481. See D'Andrea, 109 Fed. Cl. at 259-60.

482. United States v. Benchimol, 738 F.2d 1001, 1002 (9th Cir. 1984), rev'd, 471 U.S. 453 (1985). 
defendant is not the prosecutor's client." 483 The Supreme Court later agreed with the dissent's reasoning, concluding that Federal Rule of Criminal Procedure 11 did not suggest the implied-in-law requirement that the prosecutor clearly make a sentencing recommendation and express the justification for it. ${ }^{484}$

While the Benchimol Court was correct that Rule 11 does not imply that prosecutors have specific obligations when making a sentencing recommendation, it is important to note that the Due Process Clause may require more than the Federal Rules. In its 1969 opinion in Boykin v. Alabama, ${ }^{485}$ the Supreme Court held that due process requires that the record contain affirmative evidence that the defendant knowingly, voluntarily, and intelligently pleaded guilty even though no such requirement existed in Rule $11 .^{486}$ Subsequently, Rule 11 was amended in 1974 to require judges to ensure that defendants understand both the rights they are waiving by pleading guilty and the consequences of guilty pleas. ${ }^{487}$ Courts across the country have concluded that the implied covenant of good faith and fair dealing applies to plea agreements, and this Article has argued that this result is constitutionally required. If both of these premises are correct, then courts should conclude that the Due Process Clause obligates prosecutors to clearly make sentencing recommendations and express the justifications for them.

Courts could reach this conclusion despite the fact that the defendant is not the prosecutor's client. After all, although the defendant is not the prosecutor's client, the Due Process Clause obliges prosecutors to disclose material exculpatory evidence to defendants, as does Model Rule of Professional Responsibility 3.8(d). ${ }^{488}$ Model Rule 3.8 covers "Special Responsibilities of a Prosecutor." 489 Comment 1 to that Rule states in relevant part that "[a] prosecutor has the responsibility of a minister of justice and not simply that of an advocate. This responsibility carries with it specific obligations to see that the defendant is accorded procedural justice ...."490

483. Id. at 1004 (Wallace, J., dissenting).

484. United States v. Benchimol, 471 U.S. 453, 455 (1985).

485. 395 U.S. 238 (1969).

486. Id. at 242-44; see also McCarthy v. United States, 394 U.S. 459, 464-67 (1969).

487. See FED. R. CRIM. P. 11 advisory committee's notes to 1974 amendment ("The amendment ... codifies ... the requirements of Boykin v. Alabama.").

488. See supra text accompanying notes 309-12.

489. MODEL RULES OF PROF'L CONDUCT r. 3.8 (AM. BAR ASS'N 2017).

490. Id. at cmt. 1. 
Even though Rule 3.8 does not explicitly reference plea agreements, courts have applied it to the plea-bargaining process. For instance, the Supreme Court of South Dakota found that a prosecutor violated Rule 3.8 by including a clause in a plea agreement "calling for the public release of grand jury transcripts." 491 Meanwhile, the Supreme Court of Kentucky used Rule 3.8 to conclude that a prosecutor committed misconduct by including an ineffective assistance of counsel waiver in a plea agreement. ${ }^{492}$ According to the court, "[a] prosecutor is charged with 'see[ing] that the defendant is accorded procedural justice,' and we simply do not believe the use of IAC waivers lives up to that lofty expectation." ${ }^{493}$ Similarly, in the previously mentioned Foster case, the Court of Appeals of Kansas concluded that a prosecutor must make clear that the recommended sentence in a plea agreement is "worthy or desirable" 494 because of "the special duties and responsibilities of prosecutors, "whose interest ... in a criminal prosecution is not that it shall win a case, but that justice shall be done." "495

While the obligations of Rule 3.8 are not constitutionally required, there is a good argument under this Article's thesis that the implied covenant and the duty to cooperate should automatically apply at sentencing hearings and require prosecutors to make sentencing recommendations clearly and express the justifications for them. Once again, in the absence of such an automatic application, courts would need to consult the three Eldridge factors.

The same analysis applies here as applied in the substantial assistance motion context: (1) defendants in both contexts have a uniquely compelling interest in the accuracy of their criminal proceedings, (2) the government's countervailing interest in both cases must be tempered by the interest in a fair and accurate adjudication of criminal cases, and (3) defendants in both situations face a substantial risk of erroneous deprivation of their liberty that can easily be remedied by requiring the prosecution to act in good faith in presenting plea agreements at sentencing hearings. Moreover, while review of a prosecutor's failure to file a substantial assistance

491. In re Discipline of Russell, 797 N.W.2d 77, 82, 87-89 (S.D. 2011).

492. See United States ex rel. U.S. Attorneys for the E. \& W. Dists. of Ky. v. Ky. Bar Ass'n, 439 S.W.3d 136, 157 (Ky. 2014).

493. Id. (quoting KY. RULES OF PROF'L CONDUCT r. 3.130(3.8) (Westlaw through May 2018 amendments)).

494. State v. Foster, 180 P.3d 1074, 1078-79 (Kan. Ct. App. 2008) (first quoting Recommend, AMERICAN HeRITAge Dictionary 1460 (4th ed. 2000); and then quoting State v. Pabst, 996 P.2d 321, 328 (Kan. 2000)).

495. Id. at 1079 (quoting Berger v. United States, 295 U.S. 78, 88 (1935)). 
motion requires fact-finding regarding the quality and quantity of the defendant's assistance, an appellate court would merely need to look at the sentencing hearing record to decide whether a prosecutor made a sentencing recommendation clearly and expressed the justifications for it.

\section{CONCLUSION}

In his dissenting opinion in Ricketts $v$. Adamson, Justice Brennan proposed the idea of plea agreements as constitutional contracts and lamented the fact that the Supreme Court had not yet developed clear rules of construction to apply in plea-bargaining disputes. This gap in the law still exists thirty years later, despite ninety-five percent of criminal cases being resolved by plea agreements. The Supreme Court's case law, however, makes clear that the Due Process Clause applies to all parts of the plea-bargaining process and that pleading defendants should be treated at least as well as parties to other contracts. It is clear, however, that most courts treat defendants worse in at least three key plea-bargaining scenarios: (1) substantial assistance motions, (2) Brady disclosures, and (3) prosecutorial presentation of sentencing recommendations. Under a theory of plea agreements as constitutional contracts, courts should change the way they handle these three scenarios to protect the due process rights of pleading defendants. 
